\title{
THE CUMULATIVE IMPACT OF HEALTH, ENVIRONMENTAL, AND SAFETY CONCERNS ON THE CHEMICAL INDUSTRY DURING THE SEVENTIES*
}

\author{
Fred HOERGER $†$ \\ WILLIAM H. BEAMER** \\ AND JAMES S. HANSON††
}

I

INTRODUCTION

\section{Five Technical and Societal factors Influencing the Health, Environmental, and Safety Practices of the Chemical INDUSTRY}

Undoubtedly the chemical industry is different today than it was at the start of the 1970's. An examination of the four issues of Chemical Week for May 1981 reveals twenty-three articles concerning health, environmental, and/or safety (HE\&S) regulations, laws, or technology (29\% of all articles). In contrast, the corresponding issues for 1970 contained only seven articles on these topics (12\% of all articles). At least twenty-two laws regulating health, the environment, and safety were enacted during the 1970's.' The evolution of the chemical industry is a result of at least five significant technical and societal factors: (1) dramatic advances in

Copyright (C) 1983 by Law and Contemporary Problems

* The authors are indebted to K.L. Burgess, J.W. Conder, R.L. Hagerman, L. Hampton, P.A. Leeck, and M.L. Wulf for thoughtful contributions and research, and for editorial assistance.

$\dagger$ Director, Regulatory \& Legislative Issues, Health \& Environmental Sciences, The Dow Chemical Company, Midland, Michigan.

** Science Issues Manager (retired), The Dow Chemical Company, Midland, Michigan.

t† Senior Attorney, The Dow Chemical Company, Midland, Michigan.

1. Federal Environmental Pesticide Control Act, 7 U.S.C. $\$ 136$ (1982); Federal Insecticide, Fungicide \& Rodenticide Act, 7 U.S.C. $\$ 136$ (1982); Federal Hazardous Substances Labeling Act, 15 U.S.C. § 1261 (1982); Child Protection \& Toy Safety Act, 15 U.S.C. \$§ 1261-1262, 1274 (1982); Poison Prevention Packaging Act, 15 U.S.C. $\$ 1471$ (1982); Consumer Products Safety Act, 15 U.S.C. $\$ 2051$ (1982); Toxic Substances Control Act, 15 U.S.C. $\$ 2601$ (1982); Federal Food, Drug \& Cosmetic Act, 21 U.S.C. $\$ 301$ (1976); Occupational Safety \& Health Act, 29 U.S.C. $\$ 651$ (1976); Federal Mine Safety \& Health Amendments Act of 1977, 30 U.S.C. $\S \S 95$ 1-955 (Supp. V 1981); Federal Water Pollution Control Act, 33 U.S.C. $\S 1251$ (Supp. V 1981); National Cancer Act, 42 U.S.C. $\$ 281$ (1976); National Cancer Act Amendments, 42 U.S.C. $\S \S 282,286 a-286 d, 289(1)$-(4) (1976); Safe Drinking Water Act, 42 U.S.C. $§ 300 f$ (1976); Clean Air Act, 42 U.S.C. $\S 1857$ (1976); Motor Vehicle Air Pollution Control Act, 42 U.S.C. § 1857f-l (1976); National Environmental Policy Act, 42 U.S.C. $\$ 4321$ (1976); Resource Conservation \& Recovery Act, 42 U.S.C. $\$ 6901$ (1976); Solid Waste Disposal Act, 42 U.S.C. $\$ 6901$ (1976); Clean Air Act Amendments of 1977, 42 U.S.C. $\$ 7410$ (Supp. III 1978); Comprehensive Environmental Response, Compensation \& Liability Act, 42 U.S.C. $\S 9601$ (1976); Hazardous Materials Transportation Act, 49 U.S.C. $§ 1801$ (1976). 
health, environmental sciences, and control technology; (2) expanding concepts of corporate responsibility; (3) increases in media sensationalism, interest group advocacy, and public participation; (4) dramatic expansion of the laws and regulations impinging on the chemical industry; and (5) an increasing number of liability suits.

All of these factors are interrelated. For example, new knowledge of health effects could lead to a new dimension of corporate responsibility, increased advocacy, more laws, or more liabililty suits. More specifically, discovery of the linkage between exposure to vinyl chloride and the occurrence of angiosarcoma of the liver led to extensive research into the mechanism of its causation, medical surveillance, and new regulations. ${ }^{2}$ The concept of "avoiding future vinyl chlorides" was cited in advocacy ${ }^{3}$ of the Toxic Substances Control Act (TSCA) of 1976. ${ }^{4}$

As a result of the complexity and the interrelationship of these factors, it is impossible to attribute a specific aspect of HE\&S matters solely to anyone in particular. Nevertheless, if one considers the combined intent of the laws of the 1970 's, it appears that most of the industry HE\&S practices are associated with the laws. Stated another way, visibility of and public involvement in environmental matters was so great in the 1970's that today's matrix of laws may well represent an almost complete codification of societal concerns with these matters.

The resulting changes in the chemical industry may be better understood with reference to the forces that have precipitated the current matrix of laws. Advances in toxicology have been striking inasmuch as increasingly sophisticated protocols have been developed for studying the long term and chronic effects of chemicals. Bioassays of laboratory animals with lifetime exposure to a substance were conducted relatively infrequently prior to 1970. During the 1970's, however, hundreds of such studies were conducted using dietary, inhalation, or dermal exposure routes for the test substances. ${ }^{5}$ Mechanistic studies ${ }^{6}$ involving metabolic, pharmacokinetic, and deoxyribonucleic acid (DNA) effects have become part of the research program in industry, academia, and government. Studies on carcinogenicity, mutagenicity, teratology, and behavioral effects have evolved into new subdisciplines of toxicology. ${ }^{7}$

Environmental science in 1970 was embryonic. During the 1970's studies on bioconcentration, persistence, degradability, and media transport advanced rapidly on an empirical basis. ${ }^{8}$ Underlying and unifying hypotheses are just now being formulated as the discipline emerges.

Epidemiology, the study of human populations to establish cause-effect rela-

2. See U.S. Dep't Health, Education \& Welfare, Vinyl Chloride: An Injormation Source, No. $78-1599$ (1978).

3. S. ReP. No. 698, 94th Cong. 2d Sess. 5, reprinted in 1976 U.S. CODE CONG. \& AD. News $4491,4495$.

4. 15 U.S.C. $\$ 2601$ (1982).

5. Development Planning \& Research Assoc., InC. \& ICF, Inc., Chemical Testing Industry Profile of Toxicological Testing (1978).

6. E.g., Reitz, Fox \& Quast, Mechanistic Considerations for Carcinogenic Risk Estimation: Chloroform, 46 Envtl. Health Persp. 163 (1982).

7. 2A Patty's Industrial Hygiene and Toxicology (G. Clayton \& F. Clayton 3d rev. ed. 1981).

8. Address by S. Daniels, F. Hoerger \& R. Mollenaar, Environmental Exposure Assessment: Experience Under the Toxic Substances Control Act, Symposium: Chemicals in the Environment, Copenhagen, Den. (Oct. $20,1982)$. 
tionships, received considerable emphasis during the decade. Numerous studies relating to chemical substances have frequently suggested cause-effect linkages, but less frequently have they been conclusive. ${ }^{9}$ Thus, possible linkage associations have given rise to considerable HE\&S concern and uncertainty. But the cost effectiveness and actual utility of this branch of science remains unclear. ${ }^{10}$

In 1970, analytical chemists reported the presence of substances at fractions-ofa-percent to parts-per-million in food, articles of commerce, atmosphere, water, and other media. ${ }^{11}$ Presently, sophisticated instruments and techniques can often detect and measure substances in the parts-per-billion and the parts-per-trillion ranges $^{12}$ (these methods include high-pressure liquid chromatography, capillary column gas chromatography/mass spectroscopy, and neutron activation). Extensive research and monitoring programs were instituted during the 1970's by which the application of these new tools revealed the presence of substances in our environment that were previously undetected. ${ }^{13}$

Development of new control technologies has paralleled advancements in analytical chemistry and the other health and environmental sciences; carbon absorption towers to remove trace organic compounds from water discharges or municipal water supplies, scrubbers for removing particulates, neutralization techniques, incineration technology, and separation processes are only a few. These developments were dependent upon other new technology in instrumentation, materials of construction, modeling of transport and distribution, design of new containment systems, and catalysis.

The scientific and technological advances of the 1970's have led us to the point where one expends more and more resources to detect less and less pollution achieving less and less pollution abatement.

Reduction of wastes (and thus environmental release) ${ }^{14}$ at the point of origin became a priority in the development of manufacturing processes. A whole new industry, consisting of consulting firms and equipment suppliers which offer health and environmental assessment and pollution control, has emerged. Numerous examples of improved technology have been documented. ${ }^{15}$

At the start of the 1970's, most chemical companies emphasized safety programs and maintained a medical office or department for the treatment of workrelated injuries. These activities were usually reflected in corporate policy state-

9. Scientific Bases for Identification of Potential Carcinogens and Estimation of Risks, 44 Fed. Reg. 39,859 (1979).

10. Id.

11. Address by F. Hoerger, The Need for Risk Assessment in Corporate Decision-Making, American Chemical Society, Kansas City, Mo. (Sept. 1982).

12. See, e.g., OSHA Proposed Standard for Occupational Exposure to 1, 2-dibromo-3-chloropropane, 29 C.F.R. $§ 1910.1044$ (1982).

13. Council on EnVIRonmental Quality, EnVIRonmental Quality-1978 at 139 (1978).

14. For example, waste reduction can be accomplished through increases in process efficiency through reaction kinetics, engineering advances, operations improvements and recycle and recovery. Control Measures, presented at the Executive Enterprises Toxic Substances Regulation Conference, Arlington, Va. (Nov. 1979).

15. Office of Planning \& Evaluation, U.S. Environmental Protection Agency, Dratt Report: National ACCOMPlishments in POllution Control, 1970-1980 at 90-97 (1980) [hereinafter cited as DRAFT REPORT]. 
ments. During the 1970's, corporate managements placed increased emphasis on health and the environment. Policy statements, vice-presidential titles, and new departments reflected health, environmental, and product safety or related matters in most medium-sized and larger chemical companies. ${ }^{16}$

Regulatory activity during the 1950's and 1960's could be characterized as a quiet tussle between the regulators and the regulated industry. Dr. Herman Kahn of the Hudson Institute characterized the relationship as that of a professor (the regulator) with a group of bright students (the industry). The regulator was a professional, but with a carrot in one hand and the switch of an enforcement officer at his side. During the 1970's, activist groups characterized the regulatory relationship as a mutually beneficial closed room coziness causing dramatic changes. The media, from the Washington Post to the comics, and from the network nightly news to documentaries, frequently spotlighted toxic hazards.

Environmental advocacy groups also proliferated. One result of media and advocacy activity was the provision for public participation in most of the HE\&S laws of the 1970's. Regulatory proceedings that once were considered within a fairly narrow focus of risk and economics became complex as more distant and intangible societal values entered into corporate and regulatory decisions.

Laws, regulations, and liability decisions represent long term, generic, and relatively permanent influences on the chemical industry. They strongly influence the direction of science and technology development, the concepts of corporate behavior, and the points of drama and emphasis in the media and public participation. These factors will be examined in depth in the next two sections.

\section{II}

\section{The Matrix of HE\&S Laws and Regulations Which Impinge UPON THE CHEMICAL INDUSTRY}

\section{A. The Legislative Mandates of the 1970's}

Every new chemical substance produced in the United States now requires review for potentials of unreasonable risk or for safety evaluation under TSCA, ${ }^{17}$ the Federal Insecticide, Fungicide and Rodenticide Act (FIFRA), ${ }^{18}$ or the Food, Drug and Cosmetic Act (FDCA). ${ }^{19}$ Air emissions, ${ }^{20}$ water discharges, ${ }^{21}$ and disposal of wastes $^{22}$ are also controlled under complex and comprehensive statutes. Moreover, the workplace is subject to many rigorous standards and regulations under the Occupational Safety and Health Act (OSHA). ${ }^{23}$

16. Peat, Marwick, Mitchell \& Co., An Industry Survey of Chemical Company Activities to Reduce Unreasonable Risk (Feb. 11, 1983) (prepared for the Chemical Manufacturers Association); see infra section IV.

17. 15 U.S.C. $\$ 2603$ (1982).

18. 7 U.S.C. $\$ 136(1982)$

19. 21 U.S.C. $\$ 301(1976)$,

20. Clean Air Act, 42 U.S.C. $\S 1857$ (1976); Clean Air Act Amendments of 1977, 42 U.S.C. $§ 7410$ (Supp. III 1978).

21. Federal Water Pollution Control Act, 33 U.S.C. $§ 1251$ (Supp. V 1981).

22. Resource, Conservation \& Recovery Act, 42 U.S.C. $§ 6901$ (1976).

23. 29 U.S.C. $\$ 651$ (1976). 
There are yet other important HE\&S laws which affect the chemical industry. A partial listing, shown in table 1 and illustrated in figure 1 , enumerates some two dozen significant HE\&S statutes. Fifteen of these were enacted in the 1970's and seven in the 1960's. A comprehensive list ${ }^{24}$ of major U.S. federal legislation on health, environment, and safety includes forty-eight laws of which twenty-five were enacted in the 1970's and nineteen in the 1960's.

TABLE 1

Federal Legislative ACts

(Safety, Health, and Environment)

\begin{tabular}{llr} 
& & Year \\
Acronym & & Passed \\
\hline FDA & Food \& Drug Act & 1906 \\
FIA & Federal Insecticide Act & 1910 \\
FD\&CA & Food, Drug \& Cosmetic Act & 1938 \\
FIFRA & Federal Insecticide, Fungicide, \& Rodenticide Act & 1947 \\
PCA & Pesticide Chemicals Amendment & 1954 \\
FHSLA & Federal Hazardous Substances Labeling Act & 1960 \\
CAA & Clean Air Act & 1963 \\
MVAPCA & Motor Vehicle Air Pollution Control Act & 1965 \\
SWDA & Solid Waste Disposal Act & 1965 \\
CWRA & Clean Water Restoration Act & 1966 \\
ADA & Animal Drug Amendment & 1968 \\
CPTSA & Child Protection \& Toy Safety Act & 1969 \\
NEPA & National Environmental Policy Act & 1970 \\
PPPA & Poison Prevention Packaging Act & 1970 \\
OSHA & Occupational Safety \& Health Act & 1970 \\
NCA & National Cancer Act & 1971 \\
CPSA & Consumer Products Safety Act & 1972 \\
FWPCA & Federal Water Pollution Control Act & 1972 \\
FEPCA & Federal Environmental Pesticide Control Act & 1972 \\
NCA & National Cancer Act Amendments & 1974 \\
SDWA & Safe Drinking Water Act & 1974 \\
HMTA & Hazardous Materials Transportation Act & 1975 \\
TSCA & Toxic Substances Control Act & 1976 \\
RCRA & Resource Conservation \& Recovery Act & 1976 \\
CAA & Clean Air Act Amendments & 1977 \\
CWA & Clean Water Act & 1977 \\
FMSHA & Federal Mine Safety \& Health Act & 1977 \\
CERCLA & "Superfund" (Comprehensive Environmental Response, Compensation \& & 1980 \\
& Liability Act) &
\end{tabular}

A comparison of the federal laws designed to protect health, environment, and safety reveals several salient and fundamental differences. Most of the laws primarily provide authority to control health or environmental concerns. Usually this authority is well focused and confined by the law. The Clean Air Act, ${ }^{25}$ the Water Pollution Control Act, ${ }^{26}$ and the Safe Drinking Water Act, ${ }^{27}$ for example, all focus

24. Advisory Comm'n on Intergovernmental Relations, Protecting the Environment: Politics, Pollution \& Federal Policy (1981).

25. 42 U.S.C. $\$ 7410$ (Supp. III. 1978).

26. 33 U.S.C. $\S 1251$ (Supp. V 1981).

27. 42 U.S.C. $\S 300 f$ (1976). 
Figure 1

Growth in Number of Federal Legislative Acts

(Safety, Health, and Environment)

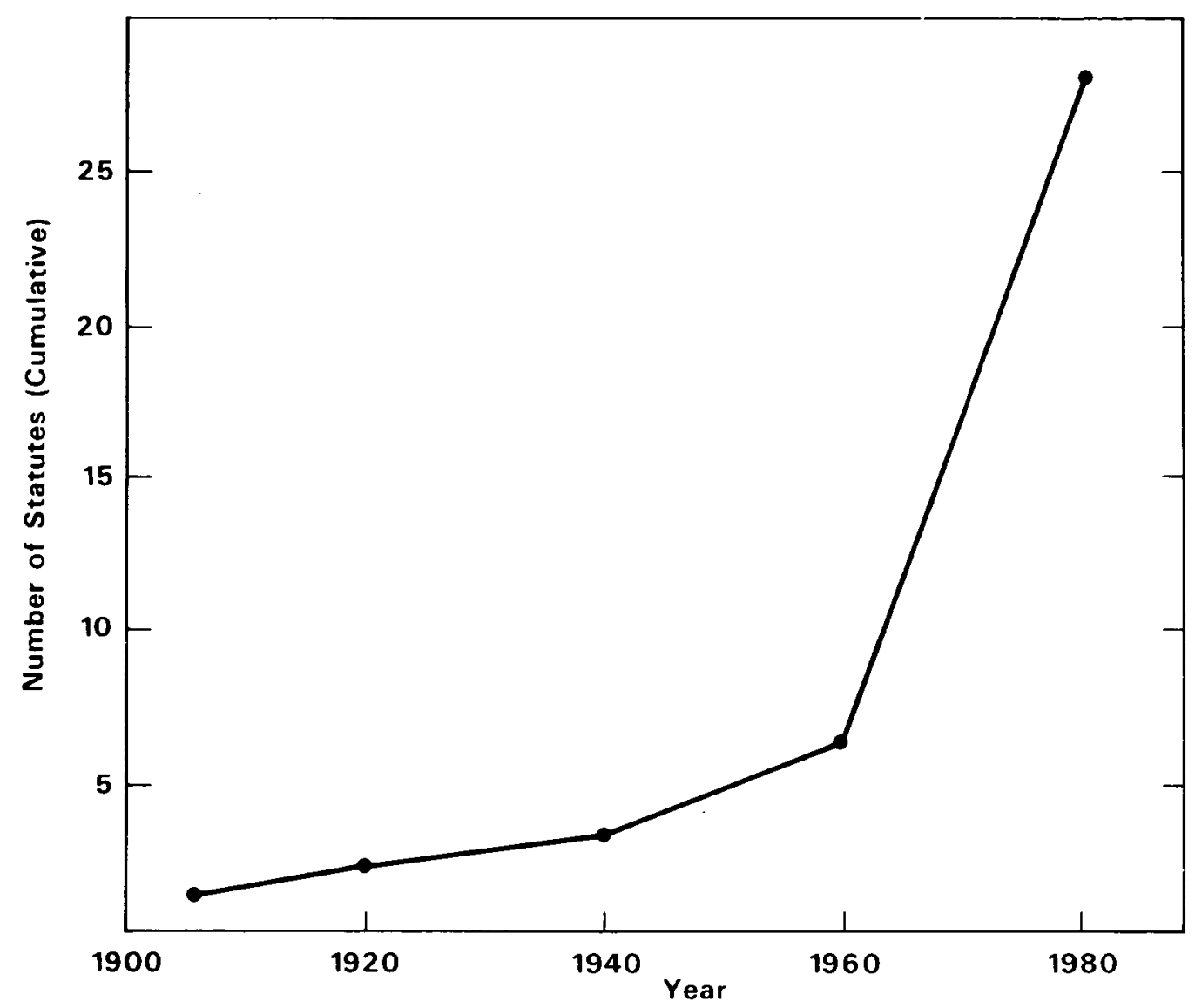

on specific media. FIFRA, FDCA, and the Resource, Conservation and Recovery Act all focus on uses of concern. OSHA focuses on workers and workplace hazards. Other statutes address the source of concern, noise ${ }^{28}$ and radiation. ${ }^{29}$

The Toxic Substances Control Act, in sharp contrast, provides authority which extends across all these boundaries of confinement, but it falls short of being a comprehensive authority for control of health and environmental concerns associated with chemicals due to the clear limitations placed on its application. Its authority is limited to "chemical substances" 30 which, by definition, ${ }^{31}$ exclude substances regulated under other health or environmentally oriented laws. The relationship of TSCA to other relevant laws is defined, and the Environmental

28. Noise Control Act, 42 U.S.C. $\$ 4901$ (1976).

29. Atomic Energy Act, 42 U.S.C. $\$ 2011$ (1976).

30. 15 U.S.C. $\$ 2602(2)$ (a) (1982).

31. Specific substances regulated under the Federal Insecticide, Fungicide and Rodenticide Act, the Atomic Energy Act, and the Federal Food, Drug and Cosmetic Act are exempted from the statutory definition of "chemical substance" under the Toxic Substances Control Act. 15 U.S.C. $§ 2602(2)(B)(1982)$. 
Protection Agency (EPA) is directed to control unreasonable risk under these other authorities, if at all possible. ${ }^{32}$ TSCA also provides the EPA with an impressive and unique array of tools for identifying, characterizing, and assessing actual or potential risk associated with chemicals. The range of authority includes the capacity to require the generation of data and information. ${ }^{33}$ The Administration is authorized to collect existing information from industry. ${ }^{34}$

FIGURE 2

Pages in the Federal Register

(thousands)

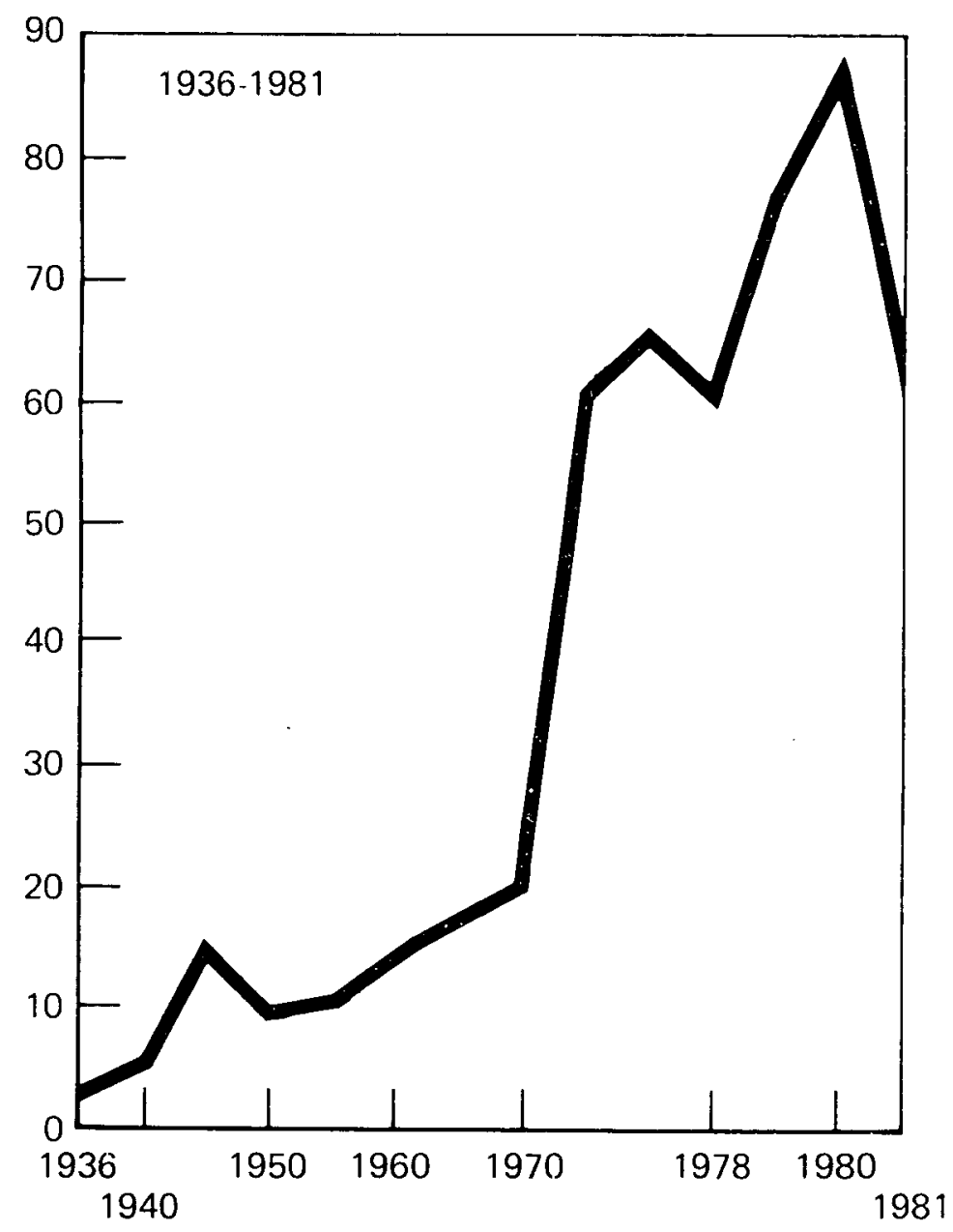

(Reproduced by permission of the publisher, REGULATORY EYE, Washington, D.C. 20006)

32. 15 U.S.C. $\S 2608$ (1982).

33. 15 U.S.C. $\$ \S 2603,2604(a)(2), 2607$ (a), 2611(b) (1982).

34. 15 U.S.C. $\S \S 2604,2607,2609-2612$ (1982). 
It is apparent, therefore, that the federal government has broad authority over HE\&S matters. Coordination of activity, avoidance of duplicative effects, and identification of jurisdictional bounds are an increasing part of the administrative management function.

\section{B. The Growth in HE\&S Regulations}

The increased number of HE\&S laws has resulted in a significant and corresponding growth in the number of regulations. The size of the Federal Register more than quadrupled from 1970 to 1980. Page counts increased from 20,000 to almost 90,000 , as shown in figure $2 .{ }^{35}$ This count, of course, reflects the activity of all federal agencies, but HE\&S items appear to have increased most rapidly.

The degree of HE\&S regulatory activity can be estimated more precisely by examination of selected portions of the Code of Federal Regulations. Data for food, drugs, occcupational safety and health, and the numerous statutes administered by the EPA are shown in table 2. This data demonstrates that the number of pages contained in regulations promulgated between 1973 and 1980 was almost three times the number promulgated previously. ${ }^{36}$ New regulations for protection of the environment increased about 4.5 times in bulk during this period.

\section{TABLE 2}

Growth of Selected Titles of the Code of Federal Regulations

Title 21 (Food \& Drugs)

Title 29, Chap. XVII

(OSHA)

Title 40 (Protection of the Environment)

Total

\begin{tabular}{cr}
\multicolumn{2}{c}{ No. of Pages } \\
\hline$\frac{1973}{1585}$ & $\frac{1980}{3500}$ \\
973 & 1500 \\
$\frac{1012}{3570}$ & $\frac{4500}{9500}$
\end{tabular}

C. A Case Example of the Interrelationship of Laws, Agency Jurisdictions, and Regulatory Controls: Vinyl Chloride

Vinyl chloride is a commodity chemical produced at an annual rate of $6,000,000,000$ to $7,000,000,000$ pounds per year. This high rate of production for vinyl chloride makes it around the tenth largest synthetic organic chemical, but this rate is much lower than that for the production of gasoline $(598,000,000,000$ pounds per year) or steel $(272,000,000,000$ pounds per year in 1979). Vinyl chloride is manufactured as a compressed gas and is used largely as a chemical inter-

35. In 1981, the number of pages in the Federal Register dropped to about 63,000. Although it is the subject of controversy, this decline can be attributed to transitional lag, as well as to a new level of regulatory activity.

36. Regulatory Eye No. 1-2 (Jan.-Feb. 1982) 
mediate or raw material to produce a polymer known as polyvinyl chloride (PVC). The polymer, manufactured as a white amorphous powder or solid, is fabricated into a wide variety of useful commercial articles such as floor tile, automobile upholstery, vinyl car tops, water pipes, rain apparel, and blood transfusion bags used in hospitals.

Five regulatory agencies have utilized nine different laws in promulgating nine regulations that are of primary importance in the manufacture and use of vinyl chloride. The regulatory activity is shown in table 3.

TABLE 3

The Matrix of Laws and Reguations impacting Manufacture AND USE OF Vinyl Chloride

\begin{tabular}{|c|c|c|}
\hline Law & Agency & Control \\
\hline Occupational Safety and Health Act & OSHA & $\begin{array}{l}\text { Workplace exposure limit and pre- } \\
\text { scribed work practices. }\end{array}$ \\
\hline Clean Air Act & EPA & $\begin{array}{l}\text { Limit on air discharge; reports required; } \\
\text { limits on residual monomer in PVC. }\end{array}$ \\
\hline Federal Water Pollution Control Act & EPA & Water Quality Criteria. \\
\hline $\begin{array}{l}\text { Federal Insecticide, Fungicide and Ro- } \\
\text { denticide Act }\end{array}$ & EPA & Use banned in pesticide formulations. \\
\hline "Superfund" & EPA & $\begin{array}{l}\text { Ethylene and chlorine, primary raw } \\
\text { materials, subject to tax for cleanup and } \\
\text { management of "orphan" hazardous } \\
\text { waste sites. }\end{array}$ \\
\hline $\begin{array}{l}\text { Hazardous Materials Transportation } \\
\text { Control Act }\end{array}$ & DOT & $\begin{array}{l}\text { Labeling and transportation safety stan- } \\
\text { dards. }\end{array}$ \\
\hline $\begin{array}{l}\text { Resources Conservation and Recovery } \\
\text { Act }\end{array}$ & EPA & $\begin{array}{l}\text { Disposal of hazardous process wastes } \\
\text { subject to standards and reports. }\end{array}$ \\
\hline Food, Drug, and Cosmetic Act & FDA & $\begin{array}{l}\text { Packaging films and water pipe subject } \\
\text { to de minimis residual monomer; plasti- } \\
\text { cizers and additives subject to approval. }\end{array}$ \\
\hline Consumer Products Safety Act & CPSC & $\begin{array}{l}\text { Use as an aerosol in consumer products } \\
\text { banned. }\end{array}$ \\
\hline
\end{tabular}

In addition to the standards and criteria of the nine principal federal regulations, the vinyl chloride and PVC plants and operations are closely scrutinized by state and local officials in review of air and water discharge permits. ${ }^{37}$ Furthermore, any new facility usually receives additional scrutiny under state or local environmental impact review procedures. Vinyl chloride illustrates the scope of regulation potentially applicable to a large-volume, chemically and biologically reactive substance.

Apart from the complex matrix of laws, regulations, and agencies, to the extent that biological properties of a substance need to be known in order to make health and environmental risk assessments, the authority of TSCA can be invoked. The

37. The states have inspection and enforcement responsibilities in the implementation of the Clean Air Act and the Federal Water Pollution Control Act. The processing of permit applications frequently involves local public hearings. 
testing of existing chemicals is authorized by TSCA on a priority basis along with control authority where other laws may not be applicable. As a consequence, premanufacture reviews, along with information gathering followup on selected new chemicals, are being conducted by the EPA. ${ }^{38}$

In summary, federal laws and regulations directly address almost every conceivable HE\&S risk imposed by a chemical in its manufacture, transportation, use, or disposal.

\section{III}

\section{TrendS IN LiabILITY SUITS}

There is little question that the chemical industry today faces new challenges in the area of products liability litigation. Civil litigation involving claimants seeking compensatory and punitive damages from members or segments of the industry increased significantly in the 1970's. ${ }^{39}$ Referred to recently as "The Widening Shadow of Product Liability," 40 the thrust of contemporary tort law has and will continue to have a decided impact on the direction and vitality of the industry as a whole. The necessary commitment of both personnel and financial resources to provide legal defense against these growing claims increases the cost of litigation. This cost will loom large on product income ledgers and personnel organization charts.

The defense of civil litigation within the industry will require sophisticated legal and scientific analysis. This type of litigation will be particularly complex with multiple high technology codefendants as named parties in litigation. Understanding myriad scientific facts and theories offered by plaintiffs and defendants will likewise be a new and difficult challenge to many courts and juries. Notwithstanding the rules of civil procedure and evidence, the offers of proof and the analysis of causation, for example, will test the legal and scientific intellect of both bench and bar as never before. Given a chance, the legal system should accommodate the complexities of litigation in a complex industry. But litigation forced through the system without a full and proper analysis of the scientific consequences and the equities would produce a difficult, undesirable, and unaccommodating regulatory regime for the industry.

Two of the greatest challenges to the industry in litigation will be related to two of the most difficult challenges that the industry has faced in the regulatory arena. First, just as the question of the proper marshalling and deployment of $\mathrm{HE} \& \mathrm{~S}$ resources has been a challenge in the regulatory arena, so it will be in private litigation. Limited resources of a chemical company can be deployed to help prepare a case for trial. Discovery and preparation in a civil case may last for years. Scientists, technicians, human health, and environmental professionals must be involved. Not surprisingly, these same people, however, have full-time

38. Reauthorization of Toxic Substances Control for Fiscal Year 1984: Hearings Before the Subcomm. on Commerce, Transportation, and Tourism of the House Comm. on Energy and Commerce, 98th Cong., 1st Sess. 33-67 (1983) (statement of Don R. Clay).

39. The Widening Shadow of Product Liability, CHemiCAL WEek, Feb. 3, 1982 at 44.

40. Id. 
jobs in addition to the assistance given to counsel in trial preparation. Likewise, other demands on these same people are already quite high. Regulatory compliance and $\mathrm{HE \& S}$ involvement in legislative and regulatory initiatives has already tended to draw these professionals away from their research toxicology and environmental labs. Without due consideration for the optimal function and deployment of these professionals in the future, the demands and exigencies of product litigation may stifle beneficial innovative research and consequent high-technology creation.

A second similarity between the regulatory and products liability challenges is the need to preserve the intellectual integrity of the decisionmaking process itself. This is only possible if plaintiffs' counsel, judges, and juries adequately consider the scientific analysis which will be necessary in the defense of a products liability suit. Fundamental fairness should not, for example, permit a civil award on a per se finding merely because a chemical product has gone through a binary regulatory analysis or generic rulemaking. Jury emotion should not be permitted to be tainted by the allegation that a plaintiff's pleading sounds pejoratively in toxic tort when indeed the legal analysis must be made in traditional terms of negligence, warranty, or strict liability. New causes of action should not be permitted because of the adverse effects on time-honored principles allocating risk. Our system of jurisprudence does not provide judicial remedies for every social and economic ill.41

Even as the incidence of product litigation in the chemical industry increases, however, general reform in products liability civil litigation is being advocated. Various legislative initiatives at both the federal and state levels have been introduced. Review of these proposals will be undertaken for years to come. If the intent of reform is to relieve the already heavy burden of civil litigation on the other nonchemical industry segments of business, presumably the legislative analysts will not overlook the serious challenges to the chemical industry which is now beginning to face the "widening shadow."

\section{Private Sector Institutionalization of HE\&S DURING THE 1970's}

Companies in the chemical industry have responded to the five technical and societal forces listed in section I in many varied ways. The actions have been evolutionary and have built upon earlier activities of some segments of the industry. These actions have led to an institutionalization of HE\&S matters in several fundamental ways: within the company organization, through joint action, and through evolving professions.

\section{A. Institutional Changes Within the Companies}

1. Management Involvement and Policy Direction. During the 1970's, company managers increasingly became involved in HE\&S matters at almost all levels. Com-

41. See Lindsey v. Normet, 405 U.S. 56, 74 (1972). 
pany presidents received information on health or environmental research activities, and business and plant managers participated in regulatory and legislative hearings as well as media events. Concurrently, company policy statements were expanded and updated to reflect greater emphasis on HE\&S matters.

The Dow Chemical Company initiated a toxicology laboratory and an embryonic environmental science program in the mid-1930's, a medical department in the 1940's, and industrial hygiene and product safety programs in the 1950's and 1960 's. ${ }^{42}$ In 1972, the management focus on these activities was formalized into a major policy statement on product stewardship. ${ }^{43}$ The Dow statement reflects a commitment to product safety in relation to employees, customers, and environmental values. Typically, management policy statements across much of the chemical industry today reflect HE\&S concern, including a commitment to occupational safety and health, environmental quality, product safety, hazard awareness, and training.

2. Organizational Structure. Examination of the organizational structures of firms shows a substantial emphasis on HE\&S activites along with an integration of the function into almost all levels of management. The function of vice president or manager of HE\&S is now an essential part of many company management structures.

Departmental or functional group titles reflect the sciences such as toxicology, human response, ecology, and medicine, as well as applied science and engineering functions such as industrial hygiene, environmental control, occupational safety, and product safety. The legal function, public relations, and the new profession of regulatory response have become highly involved in $\mathrm{HE \& S}$ matters. Another way of describing the institutionalization of HE\&S matters is that most large- and medium-sized chemical companies have integrated management styles which focus upon: data generation and literature review, communication of hazard information, assessment of HE\&S risks, risk management (the design of equipment, facilities, and operating practices to minimize risks), and regulatory response and compliance.

3. Staffing and Facilities. Staffing to concentrate on HE\&S matters increased dramatically during the 1970's. During much of the decade there was shortage of industrial hygienists, toxicologists, pathologists, occupational physicians, and epidemiologists, as industry and agencies attempted to add substantial numbers of these professionals. No data is available on the increase of these professionals in the chemical industry, but it is estimated that there has been much more than a doubling during the decade. The increase in engineers, analytical chemists, and managers in HE\&S matters has paralleled the increase in the specialty professions.

42. Dow Chemical Co., Investments in Environmental Protection: $1927-80$ at 4-10 (E. Kenaga ed. 1981).

43. The gist of this policy statement was as follows: "The Dow Chemical Company has a fundamental concern for all who make, distribute, and use its products and for the environment in which we live. This concern is the basis for our Product Stewardship philosophy by which we assess the health and environmental information on our products and then take appropriate steps to protect employee and public health and the environment." Dow Chemical Co., Product Stewardship 1 (Apr. 1, 1980). 
Based on industry observations, it is estimated that personnel involved in HE\&S matters represent $3 \%$ to $5 \%$ of the total number of employees in large chemical companies. Personnel associated with HE\&S matters probably represent approximately $10 \%$ of the professional, managerial, and administrative segment of these companies.

Investment in facilities ${ }^{44}$ represents another long term commitment by the chemical industry to HE\&S matters. Investment for data generation has been significant. The cost of a modest-size toxicological laboratory is in the range of $\$ 3,000,000$ to $\$ 5,000,000$. The installation of a water supply suitable for maintaining fish for aquatic toxicity testing costs $\$ 150,000$. A mass spectrometer, only one of many required analytical instruments, is a $\$ 300,000$ item. Thus, the cost of facilites and instruments alone often reaches unimaginable amounts.

The expansion of toxicological testing capabilities by chemical companies was, perhaps, the most dramatic investment of the 1970's. A partial list of companies with major modern facilites for toxicological testing is shown in table 4 .

TABLE 4

\title{
A Partial List of Companies with Toxicology Facilities
}

\author{
The Dow Chemical Company \\ E.I. du Pont de Nemours, Inc. \\ Eastman-Kodak Company \\ Exxon Corporation \\ Mobay Chemical Corporation \\ Mobil Corporation \\ Monsanto Company \\ Proctor \& Gamble Company \\ Shell Oil Company \\ Stauffer Chemical Company \\ Union Carbide Corporation
}

Six of these companies built their laboratories in the 1970's. The remainder expanded their facilities (by as much as 100\%) during the decade. Dow has 200,000 square feet of modern laboratory devoted to toxicology and 30,000 square feet devoted to environmental science. In addition, almost all of the companies listed in table 4 have invested in computer and data systems for analyses of medical surveillance and chemical-exposure data.

4. Hazard Communication. The volume of data and information on chemical hazards increased significantly in the 1970's. In addition to that generated by the industrial sector, important research has come from academia and the government, particularly the National Cancer Institute, other divisions of the National Institutes of Health, and the EPA. This information on potential chemical hazards is utilized and disseminated by the chemical industry in numerous ways. Labels and literature on chemicals in commerce today contain considerable information relating to safe handling and disposal, as shown in figure 3 .

Numerous other means for communicating information to the users of chemi-

44. See infra section VI. 
Figure 3

\section{PERCHLOROETHYLENE INDUSTRIAL}

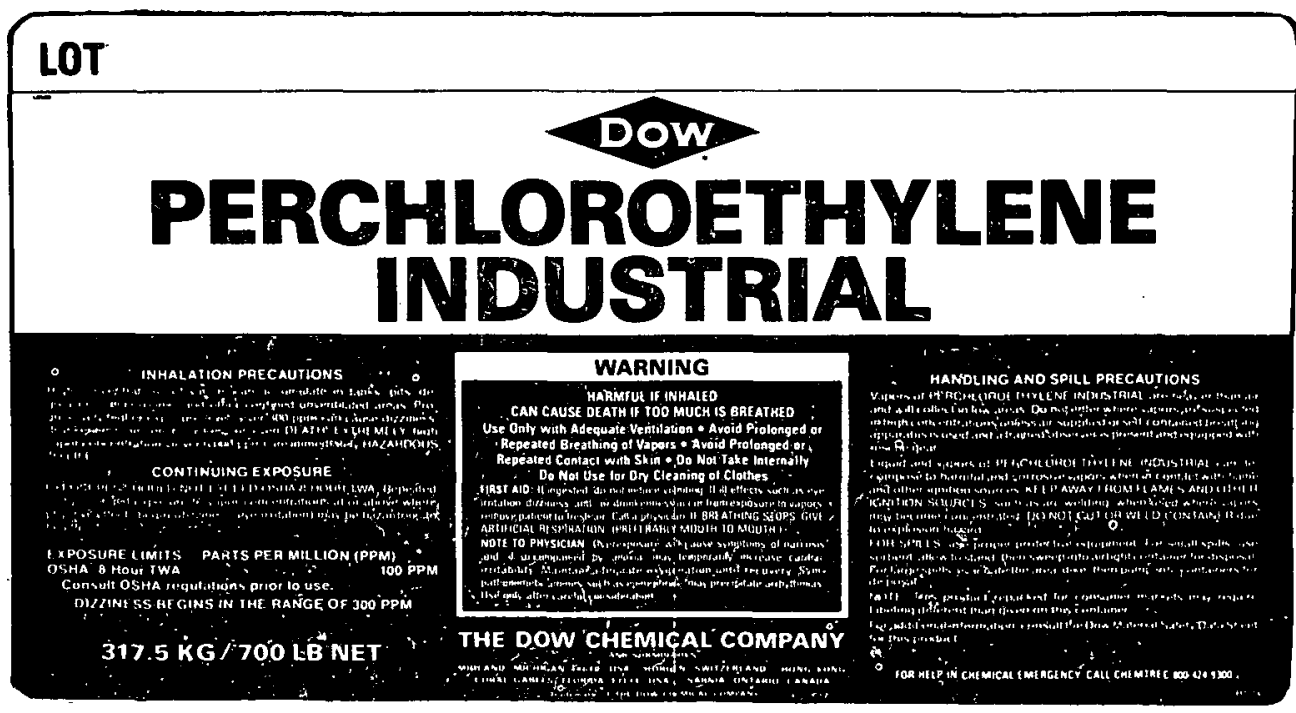

cals are in place throughout the industry, as shown in table 5. The material safety data sheets (MSDS) are distributed widely at the plant operating level and medical information sheets are located in hospital poison control centers.

Emergency response teams are on call for transportation emergencies through a national network staffed around the clock by the Chemical Manufacturers Asso-

\section{TABLE 5}

\section{EXAMPLES OF INFORMATION DISSEMINATION}

Communication Device

Material Safety Data Sheets (MSDS)

Customer Notification

Product Labels

Product Bulletins

Product Technical Literature

Medical Information Sheets

Industrial Hygiene Guides

Emergency Response Systems
Function

Provide data on a specific product or substance: physical and chemical properties, health effects data, potential hazards, first aid, and special precautions.

Provides system for automatic distribution of MSDS.

Provide users with information on product. Include precautions on hazards, directions on safe handling, storage, disposal.

Provide more detail as supplement to labels.

Brochures or booklets describing technical aspects of product including data on toxicity, flammability, hazards, and recommendations for safe handling and storage.

Condensed medical data for specific substances; include first aid and emergency treatment.

Exposure guides to control health hazards for substances for which there are no regulatory standards.

Provide expert attention to the safety aspects of transporting products, through information sheets accompanying shipments and expert teams on call to emergency sites. 
ciation. It appears that so much has been said recently about the "right-to-know" issue that one is on the verge of losing sight of how much information is available.

\section{B. Intercompany Efforts}

The industry has recognized for many years that meaningful decisions on products must be based upon sound scientific data. Although each producer has allocated resources to obtain toxicological and environmental data, the increased need has led to joint efforts. The Chemical Industry Institute of Toxicology (CIIT) was formed in 1974. Currently it has an annual budget of over $\$ 10,000,000$. The testing, research, and training programs of CIIT are supported by thirty-six member companies representing $85 \%$ of the U.S. chemical industry's production. CIIT has a current list of ten priority chemicals ${ }^{45}$ (or pairs of chemicals), selected from a candidate list of forty commodity chemicals. ${ }^{46}$ Long term toxicological studies have been completed on eight chemicals, ${ }^{47}$ and studies are under way on seven. ${ }^{48}$ Research to improve methodology and to elucidate underlying mechanisms is a prominent part of the program.

The Chemical Manufacturers Association (CMA) has established a special program whereby a number of companies with a common interest in a given chemical can develop a testing program for which the costs are shared. This program is currently concerned with twenty chemicals; the total expenditure to date has been about $\$ 16,000,000$. Additional voluntary testing programs have been undertaken by groups of chemical companies who have perceived a need for the health and safety testing of specific chemicals judged important to their companies. These groups have functioned as ad hoc industry groups or under the auspices of other trade associations. Some recent examples are the testing of: chlorobenzenes by the Synthetic Organic Chemicals Manufacturing Association (SOCMA); ${ }^{49}$ methylene chloride by the National Coffee Association; ${ }^{50}$ petroleum products by the American Petroleum Institute; ${ }^{11}$ butadiene by the International Synthetic Rubber Producers; ${ }^{52}$ and toluene diisocyanate, acrylates, ethylenediamine, and cyclopentadiene by other ad hoc groups.

In 1981, Mr. Douglas Costle, then EPA Administrator, announced the formation of the Health Effects Institute to be supported jointly by the EPA and nine automotive manufacturers. ${ }^{53}$ This Institute, located in the Boston area and

45. Chemical Industry Institute of Toxicology, Science in the Public Interest: 1981 Annual Report \& SCIEntific Review 17 (1981).

46. Id.

47. Id.

48. Id. at 19.

49. Further information is available from the Synthetic Organic Chemicals Manufacturing Association, 1075 Central Park Ave., Scarsdale, N.Y. 10583.

50. Further information is available from the National Coffee Association of the U.S.A., 121 Wall Street, N.Y., N.Y. 10005

51. Further information is available from the American Petroleum Institute, 2101 L Street, N.W., Washington, D.C. 20037.

52. Further information is available from the International Synthetic Rubber Producers, Leverkusen, W. Ger.

53. The number of supporting automotive manufacturers has since grown to 24 . 
TABLE 6

Professionalism Bridging Industry, ACADEmia, AND GOVERNMENT

1. American College of Toxicology

Bethesda, Maryland (formed in 1977)

2. Forum for the Advancement of Toxicology

Memphis, Tennessee (formed in 1968)

3. Society of Environmental Toxicology and Chemistry

Rockville, Maryland (incorporated in 1979)

4. American Chemical Society Divisions

- Environmental Chemistry (formed in 1915)

- Chemical Safety \& Health (formed in 1976)

- Pesticide Chemistry (formed in 1969)

- Committee on Chemistry and Public Affairs (formed in 1965)

5. Society for Risk Analysis

Washington, D.C. (incorporated in 1980)

6. Society of Toxicology

Akron, Ohio (formed in 1961)

7. American Occupational Medicine Association

Chicago, Illinois (formed in 1915)

directed by a prestigious board, ${ }^{54}$ has set up a research committee which has formulated a plan for research studies focused on the health effects of emissions from mobile sources. The Institute will sponsor authoritative studies at universities and leading research organizations and encourage publication of the results. It is too early to predict the outcome of this innovative and cooperative effort of the EPA and industry. However, its formation and program would appear to indicate sincere and tangible evidence of progress toward producing credible scientific data for both the regulators and the regulated.

Not to be overlooked, the Edison Electric Institute and the Electric Power Research Institute have sponsored and published research studies on the transport and deposition of gaseous and particulate emission from utility companies' plants. ${ }^{55}$

\section{Professional Activities}

Another indication of the institutionalization of HE\&S matters is found in a survey of professional activities. Various new professional organizations and societies were formed during the 1960's, and especially in the 1970's, in young disciplines like toxicology and industrial hygiene, as well as in infant disciplines like risk assessment. Table 6 lists some of these organizations with the year of their formation.

54. The three-member board consists of Archibald Cox, Donald Kennedy, and William O. Baker Doctor Walter Rosenblyth, Professor at M.I.T. chairs the Institute's Research Committee. The Institute is located at 215 First Street, Cambridge, Mass. 02142.

55. See Electric Power Research Institute, 103 Interim Report: Precipitation Data DisPLAYS FOR JANUARY 1, 1979 - JUNE 30, 1980 (May 1983). 
Scientific publications in the various HE\&S disciplines have proliferated. A few of the journals first published in the last decade are shown in table 7 . Some fortyseven titles are now on the subscription list for the Dow Health and Environmental Sciences Department library.

TABLE 7

\title{
Examples of Science Publications First Published IN THE 1970's
}

\author{
American Journal of Industrial Medicine \\ Archives of Environmental Contamination and Toxicology \\ Carcinogenesis \\ Critical Reviews in Toxicology \\ Drug and Chemical Toxicology \\ Drug Metabolism Reviews \\ Ecotoxicology and Environment \\ Environmental Health Review \\ Epidemiologic Reviews \\ Journal of Applied Toxicology \\ Journal of Environmental Economics \\ Journal of Environmental Pathology and Toxicology \\ Toxic Substances Journal
}

Additionally, weekly and biweekly newsletters covering regulatory, legislative, and scientific developments now exist. Special publications relating to public policy on HE\&S are the most recent emerging publications. Professionalism has become an institutional bridge between academia, industry, government, and other sectors.

\section{V}

\section{INDICATORS OF HE\&S Results DURING THE 1970'S}

Economists, government statisticians, and various institutions have developed elaborate sets of indicators to characterize the status and trends of our economy, such as inflation, economic growth or recession, and the relationship of government and private spending. Although there has been a decade of vigorous HE\&S activity superimposed upon considerable earlier activity, there are no indicators of HE\&S results comparable to the widely used indicators developed for the economic sector. Nonetheless, the Council on Environmental Quality (CEQ) has published annual reports ${ }^{56}$ and a special 1981 volume ${ }^{57}$ which offer glimpses of the state of HE\&S quality.

This section presents relevant evidence on the expanding knowledge base on chemicals, population, and manufacturing activity as a pressure on HE\&S quality, indications of air and water quality, trends in recycling and recovery, workplace activity, and general health trends. Society tends to describe the economy as good

56. E.g., Council on Environmental Quality, Environmental Quality- 1980 (1980) [hereinafter cited as ELEVENTH ANNUAL REPORT].

57. Council on ENVIRONMENTAL QUality, ENVIRonmental Trends (1981) [hereinafter cited as ENVIRONMENTAL TRENDS]. 
or bad, or getting better or worse. Likewise, as a matter of observation, the available data show that HE\&S trends definitely are improving.

\section{A. The Expanding Chemical Knowledge Base}

During the last decade, much has been written about the number of chemicals synthesized by man, the number of chemicals in commercial production, and the number of new chemicals introduced each year. ${ }^{58}$ Many of these commentaries imply that few of these chemicals have been tested. An analysis, however, of the universe of existing chemicals shows that the bulk of production is from a small number of substances. The data from the EPA TSCA inventory of existing chemicals reveals that about 1,000 substances represent more than $98.9 \%$ of U.S. chemical production by weight. ${ }^{59}$ The remaining 54,000 substances represent only $1.1 \%$ of chemical production. ${ }^{60}$ See table 8 .

TABLE 8

\section{Volume Distribution ENTIRE EPA INVENTORY}

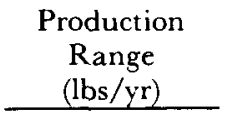

\begin{tabular}{lc}
\hline & $>10^{11}$ \\
$10^{10}$ & $10^{11}$ \\
$10^{9}$ & $10^{10}$ \\
$10^{8}$ & $10^{9}$ \\
$10^{7}$ & $10^{8}$ \\
$10^{6}$ & $10^{7}$ \\
$10^{5}$ & $10^{6}$ \\
$10^{4}$ & $10^{5}$ \\
& $<10^{4}$
\end{tabular}

\begin{tabular}{rr}
\multicolumn{2}{c}{$\begin{array}{c}\text { No. of } \\
\text { Materials }\end{array}$} \\
\hline & $\frac{\%}{0}$ \\
1 & $<0.1$ \\
95 & 0.2 \\
216 & 0.5 \\
436 & 1.1 \\
1,065 & 2.7 \\
1,983 & 5.0 \\
3,798 & 9.7 \\
4,689 & 11.9 \\
27,010 & 68.7
\end{tabular}

\begin{tabular}{rr}
\multicolumn{3}{c}{$\begin{array}{c}\text { Total Production } \\
\text { (million lbs/yr) }\end{array}$} \\
\hline$\frac{\%}{6}$ \\
102,000 & 2.5 \\
$3,119,000$ & 76.5 \\
656,000 & 16.1 \\
155,000 & 3.8 \\
33,800 & 0.8 \\
8,140 & 0.2 \\
1,720 & 0.04 \\
225 & 0.01 \\
28 & $<0.01$
\end{tabular}

Cumulative

$\%$ Production

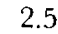

79.0

95.1

98.9

99.7

99.9

99.98

99.99

100.00

Another analysis of the inventory divides all those substances reported as produced in quantities of 1,000,000 pounds or more per year into several categories such as organics, inorganics or polymers. This important analysis is most enlightening. Those materials which can be classified as petroleum derivatives (such as gasoline, kerosene, and distillation cuts) represent $10 \%$ of the total number of entries in the inventory but account for $55 \%$ of the total production. The inorganics represent $12 \%$ of the materials and $12 \%$ of the production. Another $7 \%$ of the production is due to materials which are residues from the processing of ferrous metals. The saturated hydorocarbons (such as methane, ethane, hexane) are responsible for $7 \%$.

Of those substances produced in quantities greater than $1,000,000$ pounds per year, structurally well-defined organic substances-the materials most frequently of concern in current policies on testing-are the most numerous; they represent

58. See, e.g., H.R. ReP. No. 1341, 94th Cong., 2d Sess. 3 (1976).

59. E. Blair \& C. Bowman, Control of Existing ChemiCals-1982 (1982), reprinted from American Chemical Society Symposium Series, No. 213: TSCA's Impact on Society and Chemical Industry.

60. Id. 


\section{TABLE 9}

Volume Distribution by Type of Substance

(produced in excess of $1,000,000$ lbs. annually)

\begin{tabular}{|c|c|c|c|c|}
\hline Type of Substance & Count & $\begin{array}{c}\% \\
\text { Count }\end{array}$ & $\begin{array}{l}\text { Production } \\
\text { Volume } \\
\text { (millions) }\end{array}$ & $\begin{array}{c}\% \\
\text { Volume }\end{array}$ \\
\hline Petroleum, Primary Derivatives & 380 & 10.0 & $2,258,000$ & 55.4 \\
\hline Inorganics & 452 & 11.9 & 503,000 & 12.4 \\
\hline Metals, Refining Residues (Ferrous) & 20 & 0.5 & 281,000 & 6.9 \\
\hline Alkanes & 21 & 0.5 & 272,000 & 6.7 \\
\hline Organics & 1,307 & 34.4 & 246,000 & 6.0 \\
\hline Polymers \& Plastics & 893 & 23.5 & 122,000 & 3.0 \\
\hline Other & 18 & 0.5 & 95,000 & 2.3 \\
\hline Coal, Primary Derivatives & 30 & 0.8 & 90,500 & 2.2 \\
\hline Natural Products \& Derivatives & 254 & 6.7 & 84,200 & 2.1 \\
\hline Metals, Refining Residues (Non-Ferrous) & 52 & 1.4 & 59,700 & 1.5 \\
\hline Organics, Variable Composition & 287 & 7.6 & 27,000 & 0.7 \\
\hline Metals & 24 & 0.6 & 19,600 & 0.5 \\
\hline Minerals & 29 & 0.8 & 14,300 & 0.3 \\
\hline Alloys & 13 & 0.3 & 1,600 & 0.04 \\
\hline Dyes \& Pigments & 15 & 0.40 & 133 & $<0.01$ \\
\hline Living Organisms & 1 & 0.03 & 1 & $<0.01$ \\
\hline Total & 3,796 & 100.00 & $4,074,000$ & 100.00 \\
\hline
\end{tabular}

$34 \%$ of the inventory sample, but they account for only $6 \%$ of the total production by weight (see table 9 ). ${ }^{61}$

For another perspective, consider the production volume of new chemicals. Almost every new chemical starts as a small-volume chemical. Most never grow beyond the small-volume stage of a few thousand to 100,000 pounds per year. Those few that do grow to significant volumes do so only over a relatively long period of time, extending ten to thirty years. Based on the assumption of continued innovation of new chemicals and optimistic growth trends for these chemicals, the 1990 annual production for all new chemicals developed during the entire decade of the 1980's is estimated to be $500,000,000$ pounds. It is a comparatively small volume juxtaposed to the $565,000,000,000$ pounds of production for the "top 50 " in 1980 and an estimated 900,000,000,000 pounds for the "top 50" in the year 1990. Accordingly, the majority of exposure potentials are associated with a relatively small number of chemicals, perhaps only a few hundred. ${ }^{62}$ The fifty largestvolume chemicals produced in the United States comprise a substantial portion of the organics, alkanes, and inorganics in commercial use today--about $55 \%$ of those

61. The data used in this discussion was made available by the EPA from its TSCA inventory and does not contain precise information on production volume since such information was claimed to be confidential. Since the EPA did report production volume in ranges, in this exercise an appropriate midpoint was used for such range-except that a volume of 1,000 pounds was used for materials reported at less than 1,000 pounds, and 1,000,000,000 pounds was used for those reported at more than 1,000,000,000 pounds. Id.

62. Hoerger, Indicators of Exposure Trends, in Quantirication OF OCCUPATIONAL Cancer 440 (Banbury Report No. 9, 1981). 
TABLE 10

Summary of Data Avallable and Testing Planned on U.S. "ToP 50" Chemicals

\begin{tabular}{|c|c|c|c|c|c|}
\hline \multirow[b]{2}{*}{ Chemical Substance } & \multicolumn{3}{|c|}{ Data Available* } & \multirow[b]{2}{*}{$\begin{array}{l}\text { Testing } \\
\text { Planned or } \\
\text { Underway }\end{array}$} & \multirow[b]{2}{*}{$\begin{array}{c}\text { Scored by ITC } \\
\text { (R=Recommended }\end{array}$} \\
\hline & $\begin{array}{l}\text { Physical } \\
\text { Properties }\end{array}$ & $\begin{array}{c}\text { Human Health } \\
\text { Mammalian } \\
\text { Toxicology }\end{array}$ & $\begin{array}{l}\text { Eco- } \\
\text { toxi- } \\
\text { cology }\end{array}$ & & \\
\hline Acetic Acid & $\mathrm{x}$ & $\mathrm{X}$ & $\mathrm{X}$ & & \\
\hline Acetic Anhydride & $\mathrm{x}$ & $\mathrm{x}$ & $\mathrm{x}$ & & \\
\hline Acetone & $\mathrm{x}$ & $\mathrm{x}$ & $\mathrm{x}$ & $\mathrm{x}$ & \\
\hline Acrylonitrile & $\mathrm{x}$ & $\mathrm{x}$ & $\mathrm{x}$ & $\mathrm{x}$ & \\
\hline Adipic Acid & $\mathrm{x}$ & $\mathrm{x}$ & $\mathrm{x}$ & & \\
\hline Aluminum Sulfate & $\mathrm{x}$ & $\mathrm{x}$ & $\mathrm{x}$ & & \\
\hline Ammonia & $\mathrm{x}$ & $\mathrm{x}$ & $\mathrm{x}$ & $\mathrm{x}$ & \\
\hline Ammonium Nitrate & $\mathrm{x}$ & & $\mathrm{x}$ & & \\
\hline Ammonium Sulfate & $\mathrm{x}$ & $\mathrm{x}$ & & & \\
\hline Benzene & $\mathrm{x}$ & $\mathrm{x}$ & $\mathrm{x}$ & $\mathrm{x}$ & \\
\hline 1,3-Butadiene & $\mathrm{x}$ & $\mathrm{x}$ & $\mathrm{x}$ & & $\mathrm{x}$ \\
\hline Calcium Chloride & $\mathrm{x}$ & $\mathrm{X}$ & $\mathrm{x}$ & & \\
\hline Calcium Oxide & $\mathrm{x}$ & $\mathrm{x}$ & $\mathrm{x}$ & & \\
\hline Carbon Black & $\mathrm{x}$ & $\mathrm{x}$ & $\mathrm{x}$ & & $\mathrm{x}$ \\
\hline Carbon Dioxide & $\mathrm{x}$ & $\mathrm{x}$ & & & \\
\hline Chlorine & $\mathrm{x}$ & $\mathrm{x}$ & $\mathrm{x}$ & $\mathrm{x}$ & \\
\hline Cumene & $\mathrm{x}$ & $\mathrm{x}$ & $\mathrm{x}$ & & $\mathrm{x}$ \\
\hline Cyclohexane & $\mathrm{x}$ & $\mathrm{x}$ & $\mathrm{x}$ & & $\mathrm{x}$ \\
\hline 1,2-Dichloroethane & $\mathrm{x}$ & $\mathrm{X}$ & $\mathrm{x}$ & $\mathrm{x}$ & $\mathrm{x}$ \\
\hline Ethanol & $\mathrm{x}$ & $\mathrm{x}$ & $\mathrm{x}$ & & \\
\hline Ethyl Benzene & $\mathrm{x}$ & $\mathrm{x}$ & $\mathrm{x}$ & & $\mathrm{x}$ \\
\hline Ethylene & $\mathrm{X}$ & & $\mathrm{x}$ & $\mathrm{x}$ & $\mathrm{x}$ \\
\hline Ethylene Glycol & $\mathrm{x}$ & $\mathrm{x}$ & $\mathrm{X}$ & $\mathrm{x}$ & $\mathrm{x}$ \\
\hline Ethylene Oxide & $\mathrm{x}$ & $\mathrm{x}$ & $\mathrm{x}$ & $\mathrm{x}$ & $\mathrm{R}$ \\
\hline Formaldehyde & $\mathrm{x}$ & $\mathrm{x}$ & $\mathrm{x}$ & $\mathrm{x}$ & $\mathrm{x}$ \\
\hline Hydrochloric Acid & $\mathrm{x}$ & $\mathrm{x}$ & $\mathrm{x}$ & & \\
\hline Methanol & $\mathrm{x}$ & $\mathrm{x}$ & $\mathrm{x}$ & $\mathrm{x}$ & \\
\hline Nitric Acid & $\mathrm{x}$ & $\mathrm{x}$ & $\mathrm{x}$ & & \\
\hline Nitrogen & $\mathrm{x}$ & & & & \\
\hline Oxygen & $\mathrm{x}$ & & & & \\
\hline Phenol & $\mathrm{x}$ & $\mathrm{x}$ & $\mathbf{x}$ & $\mathrm{x}$ & \\
\hline Phosphoric Acid & $\mathrm{x}$ & $\mathrm{x}$ & $\mathrm{x}$ & & \\
\hline Propanol & $\mathrm{x}$ & $\mathrm{x}$ & $\mathrm{x}$ & & \\
\hline Propylene & $\mathrm{X}$ & & $\mathrm{x}$ & & $\mathrm{x}$ \\
\hline Propylene Oxide & $\mathrm{x}$ & $\mathrm{x}$ & $\mathrm{x}$ & $\mathrm{x}$ & $\mathbf{R}$ \\
\hline Sodium Carbonate & $\mathrm{x}$ & $\mathrm{x}$ & & & \\
\hline Sodium Hydroxide & $\mathrm{x}$ & $\mathrm{x}$ & $\mathrm{x}$ & & \\
\hline Sodium Sulfate & $\mathrm{x}$ & $x$ & $\mathrm{x}$ & & \\
\hline Sodium Tripolyphosphate & $\mathrm{x}$ & $\mathrm{x}$ & $\mathrm{x}$ & & \\
\hline Styrene & $\mathrm{x}$ & $\mathrm{x}$ & $\mathrm{x}$ & $\mathrm{x}$ & $\mathrm{x}$ \\
\hline Sulfuric Acid & $\mathrm{x}$ & $\mathrm{x}$ & & & \\
\hline Terephthalic Acid & $\mathrm{X}$ & $\mathrm{X}$ & & $\mathrm{x}$ & $\mathrm{x}$ \\
\hline Titanium Oxide & $\mathrm{X}$ & $\mathrm{x}$ & $\mathrm{x}$ & $\mathrm{x}$ & $\mathrm{x}$ \\
\hline Toluene & $\mathrm{x}$ & $\mathrm{x}$ & $\mathrm{x}$ & & $\mathrm{R}$ \\
\hline Urea & $\mathrm{x}$ & $\mathrm{x}$ & $\mathrm{x}$ & $\mathrm{x}$ & \\
\hline Vinyl Acetate & $\mathrm{x}$ & $\mathrm{x}$ & $\mathrm{x}$ & $\mathrm{x}$ & \\
\hline Vinyl Chloride & $\mathrm{x}$ & $\mathrm{x}$ & $\mathrm{x}$ & $\mathrm{x}$ & \\
\hline Water Glass & $\mathrm{x}$ & $\mathrm{x}$ & & & \\
\hline p-Xylene & $\mathrm{x}$ & $\mathrm{x}$ & $\mathrm{x}$ & $\mathrm{x}$ & $\mathrm{R}$ \\
\hline Xylene & $\mathrm{x}$ & $\mathrm{x}$ & $\mathrm{x}$ & $\mathrm{x}$ & $\mathrm{x}$ \\
\hline
\end{tabular}

* Results of preliminary search; it is not exhaustive and does not reflect proprietary data. 
produced in excess of 1,000,000 pounds per year. A recent appraisal indicated data exists on the health and environmental effects on almost all of those produced in the United States (see table 10).

To obtain a general knowledge for the range and depth of data, but without an exhaustive search, the accumulated information on the physical, chemical, toxicological, and ecological properties of these fifty substances was examined. The amount of data available varied for each chemical, as is normally expected. However, physical and chemical properties data were available on all fifty. There were only five substances for which there was no information on human health and mammalian toxicology, and in every case, these substances were well known and they were not expected to present a problem. There was less data on ecotoxicology, but still there was data for all but eight substances: ammonium sulfate, carbon dioxide, sodium carbonate, nitrogen, oxygen, sulfuric acid, terephthalic acid, and water glass. The Interagency Testing Committee (ITC) (chartered by TSCA) has also examined these chemicals. Of the fifty substances, only eighteen "survived" the initial screening process used by the ITC to narrow down the total number of substances that might have data gaps of a priority nature. Each of these eighteen was scored, using the ITC scoring procedures, and was then considered more comprehensively by the committee. Only four have been recommended for priority testing: ethylene oxide, propylene oxide, toluene, and p-xylene. The testing programs of the CIIT and the CMA include twenty-one of the top fifty substances (either being tested or being considered for testing) ${ }^{63}$

In summary, the fifty largest-volume chemicals represent production volumes far in excess of the volumes for other structurally defined substances. Their volume also far exceeds that projected for new chemicals. The data base on these chemicals is significant, and the priority data gaps, as perceived by either industry or government, are being filled.

It is likely that, in the foreseeable future, testing priorities will shift toward intermediate-volume or smaller-volume chemicals. This means that the testing efforts will, in general, be targeted at a realm of lesser exposure potential than at present. Thus, it is not unlikely that the yield from traditional toxicological and environmental testing will diminish in terms of risk reduction potential.

\section{B. Population and Manufacturing Activity as a Pressure on HE\&S Quality}

It is at least arguable that growth in population and growth in gross national product (GNP) may roughly limit man's adverse effect on HE\&S quality. As a lower limit of pressure on HE\&S quality, more people at a constant standard of living require more goods. As an upper threshold, the growth in the GNP reflects growth in aggregated activities which produce goods and services that may threaten the environment. The U.S. population increased by $11 \%$ from 1970 to $1980(205,000,000$ to $228,000,000)$. The GNP increased by about $41 \%$ in constant dollars, as shown in table 11 .

63. E. BLAIR \& C. BowmAN, supra note 59. 
TABLE 11

Gross National Pronuct by Year

(billions of dollars)

$\underline{\text { Year }}$

1970

1975

1980

1981 (3rd Qtr.)
In Current Dollars

992.7

1549.2

2626.1

2956.6
In Constant (1972) Dollars

1,075

1,202

1,481

1,516

Source: U.S. Dep't of Commerce, Statistical AbStracts of the U.S., U.S. Dep't of ComMerce Survey of CurRent Business (1980).

Support for this model of environmental pressure is provided by examination of underlying data. Employment in U.S. manufacturing plants increased only about 5\% during the 1970's, to just over 20,000,000. Employment in the chemical and allied products industry was essentially constant at 1,100,000 workers. Results are as shown in table 12.

Physical output of the heavier industries has increased only modestly during the 1970's, as shown by selected data in table 13 .

The chemical industry has grown rapidly since World War II. However, the more rapid rate of growth occurred in the period from 1945 to 1970 . Two indicators of growth in the chemical industry are shown in figures 4 and 5 . These figures show the rate of growth of the synthetic organic chemical industry and of a grouping of the fifty largest-volume chemicals (a mix of both organic and inorganic chemicals). The physical output of the chemical industry grew less than $50 \%$ during the decade according to these indicators. It is evident from the foregoing data that without changes in HE\&S technology, the United States would have experienced a greater than $10 \%$ deterioration in HE\&S quality during the seventies (simply from population growth). Real growth in the GNP would place the upper limit of deterioration at $40 \%$.

TABLE 12

Change in WORKFORCE

(number of employees in thousands)

\begin{tabular}{lc}
$\frac{\text { Year }}{1970}$ & Mfg. Industry \\
\cline { 2 - 2 } 1975 & 19,367 \\
1980 & 18,323 \\
1981 (Oct.) & 20,238 \\
& 20,350
\end{tabular}

Chemical and Allied

Products Industry

Source: Handbook of Basic Economic Statistics (1981) 


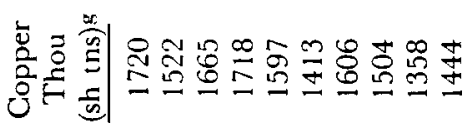

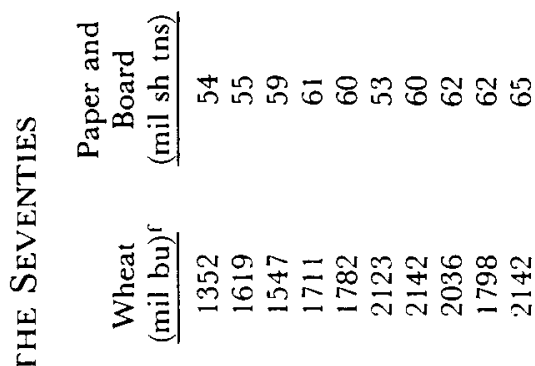

崩

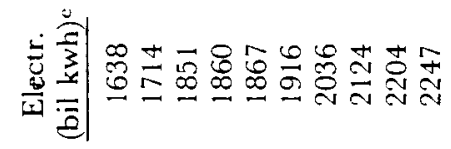

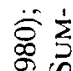

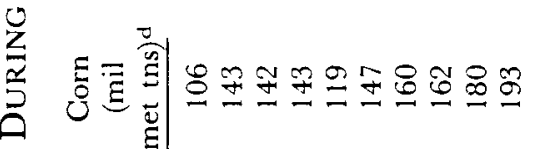

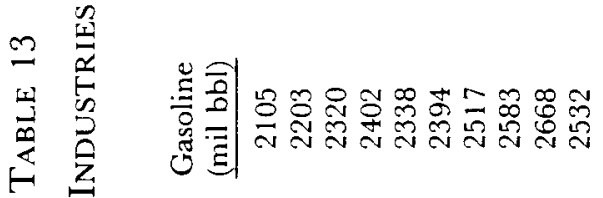

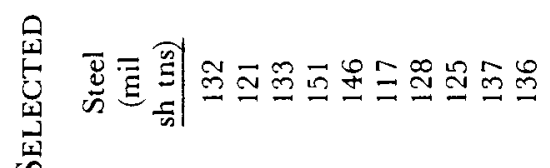

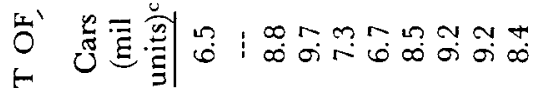

它

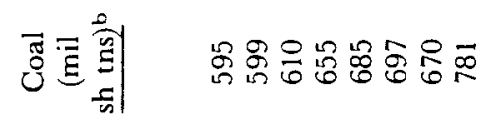

$\frac{0}{0}$

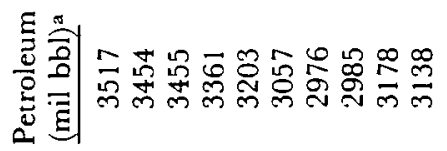


Figure 4

U.S. Production of Synthetic Organic Chemicals, 1940-1979 (billions of pounds)

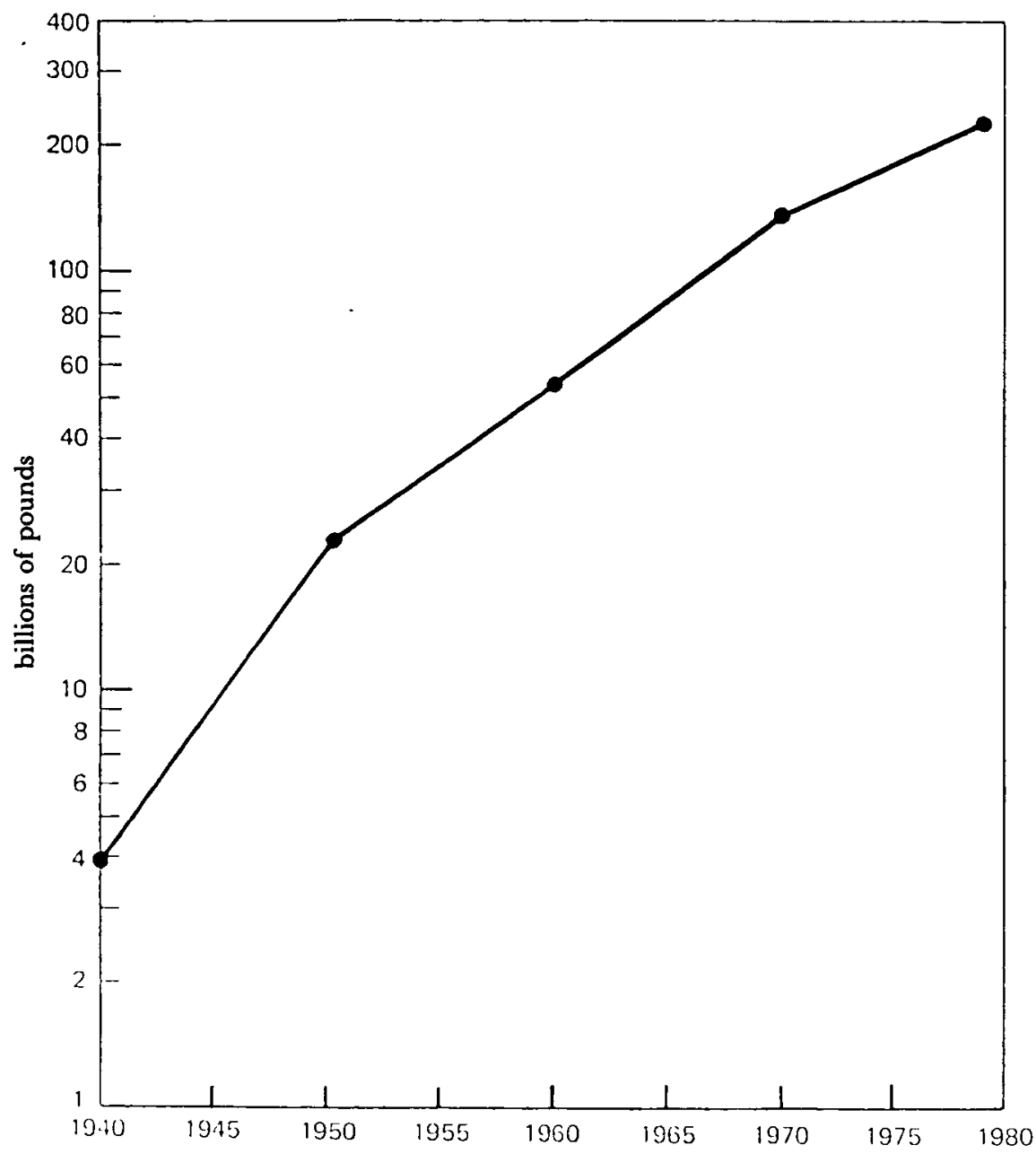


Figure 5

Production Volume

The Top 50 U.S. Chemicals, 1971-1979

(billions of pounds)

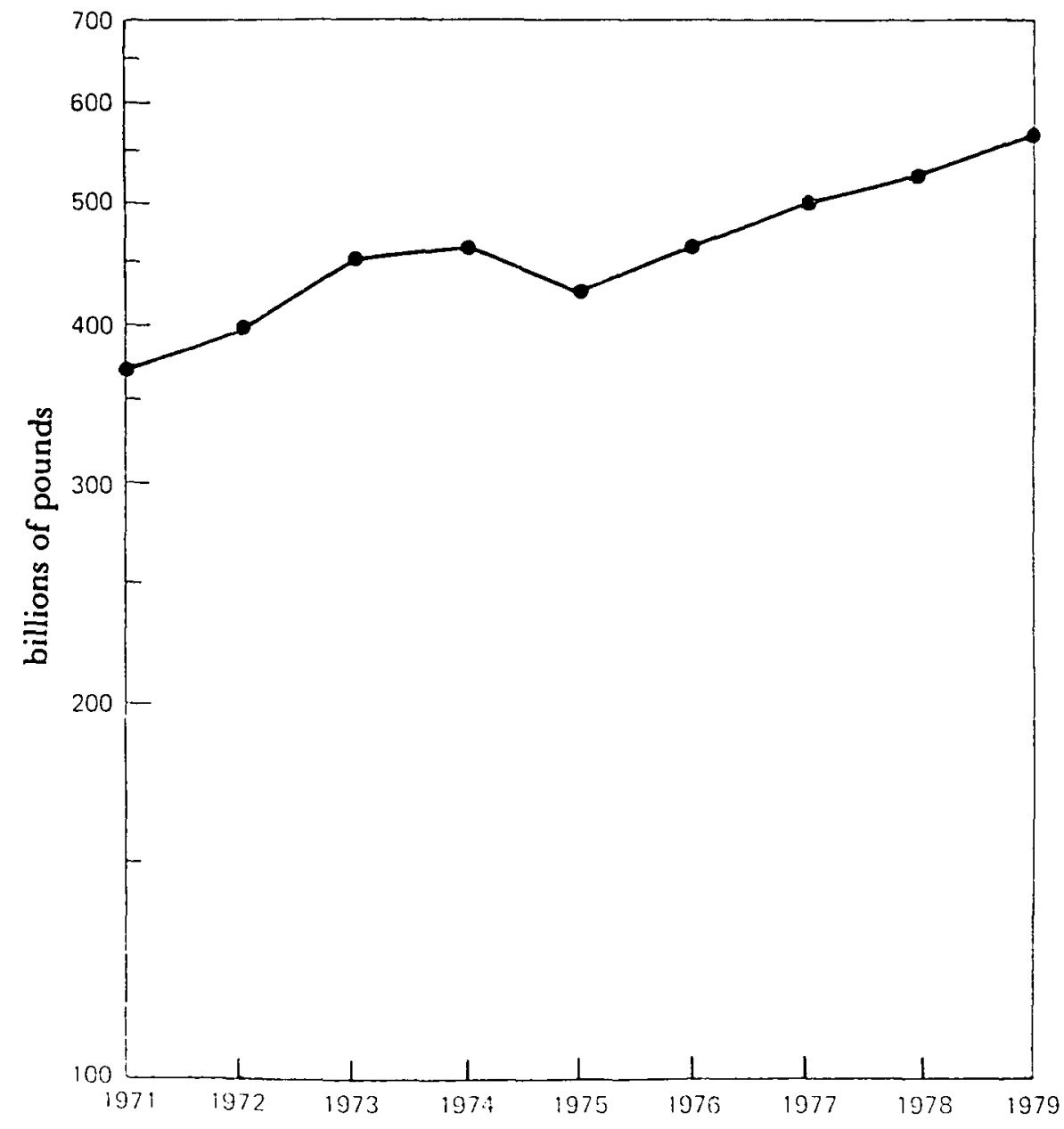

C. Improvements in Environmental Quality

A careful search for information and data on environmental quality yields a moderate amount of fragmentary and indirect evidence. Within their limitations, this information indicates significant improvement.

1. Air Quality. Over the last decade air quality has improved considerably based on most analyses of monitoring data. Six substances were identified by law in 1970 
as criteria air pollutants. ${ }^{64}$ Since then, ambient air quality standards have been established as a basis for a complex system of controls by federal, state, and local air pollution control agencies. ${ }^{65}$ Ambient concentrations of carbon monoxide have decreased by more than $40 \%$ over the past ten years. The standard is expected to be attained throughout the country before 1987. The present EPA leadership refers to carbon monoxide as a vanishing problem. ${ }^{66}$ Sulfur dioxide levels declined more than $20 \%$ during the same period. ${ }^{67}$ In 1979, standards were exceeded on fewer than ten days in most places. ${ }^{68}$

During the 1970's, emissions of particulate matter from industrial sources were reduced by $50 \%$, while particulate air quality levels improved by only $20 \% .{ }^{69}$ This disparity occurs because many of the monitors also register nonindustrial dusts such as wind-blown soil. The present standard does not distinguish particulates by size, toxicity, or origin. ${ }^{70}$ Most industries have installed control equipment which captures more than $90 \%$ of the particulate matter, and many capture more than $99 \% .{ }^{71}$ Airborne lead has decreased in the urban atmosphere as the aggregate lead content of gasoline has decreased over the past ten years. ${ }^{72}$ Metal concentrations also have decreased generally. ${ }^{73}$ Ozone measurements are used as an indication of photochemical smog; however, a clearly defined trend in the levels of smog pollution cannot be ascertained from the data available at this time.

The EPA's roll-back formula for control of hydrocarbons was abandoned as illconceived and ineffective. ${ }^{74}$ Consequently, hydrocarbons were dropped as a criteria pollutant. Nitrogen dioxide, although designated as a criteria pollutant, has not assumed the importance of other pollutants. The ambient standard for the latter pollutant is exceeded only in a few areas, and in those areas, measurements are only slightly higher than the standard. The EPA now regards nitrogen dioxide as a minor problem of declining significance. As a more general profile of air quality, the EPA maintains a composite index for twenty-three urban areas (standard metropolitan statistical areas). ${ }^{75}$ The agency tabulates the number of days in the combined cities in which one or more of the criteria pollutants exceeds the national ambient standards. Table 14 shows that the index has improved for the three levels of general pollution.

64. 42 U.S.C. $\S 1857(1976)$.

65. Eleventh ANNUAL RePORT, supra note 56, at 172.

66. Bennett, Why the Clean Air Act Needs Amendment, EPA J., Sept.-Oct. 1981, at 4.

67. Eleventh ANNUAL RePORT, supto note 56, at 167.

68. National Commission on Air Quality, To Breathe Clean Air 115 (1981).

69. Address by former EPA Administrator Gorsuch to Air Pollution Control Association (June 22, 1981), reprinted in EPA J., July-Aug. 1981, at 2.

70. Primary and secondary standards for particulate matter (dust) were promulgated on April 30, 1971 and are now contained in National Primary and Secondary Ambient Air Quality Standards, 40 C.F.R. $\S \S 50.6,50.7$ (1982).

71. Bennett, supra note 66 , at 4 .

72. ENVIRONMENTAL TRENDS, supra note 57 , at 283.

73. Id.

74. Lave \& Omenn, Clearing the Air: Reforming the Clean Air Act (1978) (unpublished manuscript, staff paper for the Brookings Institution).

75. Eleventh ANNUAl Report, supra note 56, at 147. 
TABLE 14

IMPROVEMENT IN THE AIR QUALITY INDEX

Combined Pollutant Standard Index For Twenty-three SMSA's ${ }^{(\mathbf{a})}$

\begin{tabular}{lrrr}
\hline & 1974 & 1978 & \% Change \\
\cline { 2 - 2 } & 1985 & 1637 & -18 \\
Very Unhealthful & 547 & 358 & -35 \\
Hazardous & 33 & 15 & -55
\end{tabular}

(a) Standard Metropolitan Statistical Areas

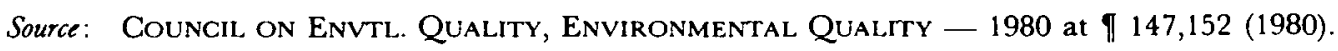

Measurements of one specific hazardous substance, benzoapyrene, in the atmosphere at twenty-six urban centers, has shown a decrease of about $88 \%$ (from 4.5 to 0.5 nanograms per cubic meter) in the period 1969 to $1977 .^{76}$

2. Water Quality. The principal sources of pollution in lakes and rivers are municipal sewage systems, industrial discharges, and agricultural and urban runoff. ${ }^{77}$ The control of industrial discharges has improved greatly. ${ }^{78}$ Some progress has been made in municipal sewage discharges, but little has been done in the area of run-off contamination.

During the 1970's about $70 \%$ of the U.S. population had sewer service. Between 1970 and 1978 those with sewer service, but whose sewage was not treated, decreased from $29 \%$ to $1 \% ;{ }^{79}$ however, those that had sewer service were receiving only primary treatment of the sewage. Bacterial population levels in the waterways throughout the country indicate that sewage treatment plants are still major offenders to water quality ${ }^{80}$ Pesticidal residues in river sediments, in fish, and in birds have decreased over the past decade. ${ }^{81}$ The persistent chlorinated organics such as DDT, dieldrin, and chlordane show steep downward detection trends. ${ }^{82}$ The DDT levels in Lake Michigan fish have declined $90 \%$ since $1969 .{ }^{83}$

In recent years, substantial improvements in water quality have been made in many rivers and lakes in the United States. For instance, the Connecticut River had not supported the Atlantic salmon since 1874 until the cleanup of the 1970's made it possible for salmon to live in its waters again. The Willamette River in Oregon has been the subject of pollution abuse for over sixty years. But due to continuing efforts, the past ten years have seen the construction of waste treatment facilities and controls of discharges, and the river has returned to "swimmable and fishable" status. ${ }^{84}$

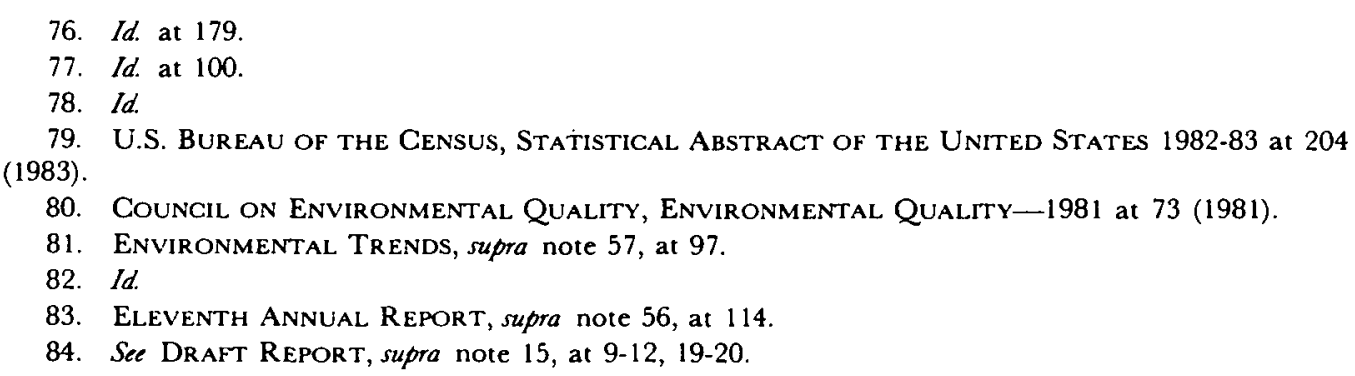


3. Conservation, Recycling, and Waste Recovery. Fragmentary data suggest that, when economically feasible, conservation, recycling, and recovery are quickly adopted and utilized. Accordingly, energy conservation programs were implemented extensively by industry in the mid-1970's. The recovery and recycling of materials from solid waste has received considerable impetus, especially in such items as aluminum and iron. On balance, progress has been made, but at a relatively slow rate. Although solid waste has continued to increase in the United States, the percentage of recycling from the solid waste stream has also improved (see table 15):

TABLE 15

SOLID WASte Recovery

$\begin{array}{llll} & \underline{1960} & \frac{1970}{1977} \\ \text { Waste/person (lbs.) } & 2.64 & 3.5 & 3.73 \\ \text { Recovery/person (lbs.) } & 0.18 & 0.21 & 0.30 \\ \% \text { Recovery } & 6.8 \% & 6.9 \% & 8.0 \%\end{array}$

Source: U.S. Dep't of Commerce, Statistical abstract of the U.S., U.S. Department of Commerce Survey of Current Business 213 (1980).

As a sign of progress, it should be noted that the point has nearly been reached when the increase in waste per person that actually goes to disposal has begun to level off (3.3 pounds in 1970 compared to 3.4 pounds in 1977).

A second area of marked improvement in recycling is water resources. In recent years, the significance of this resource has resulted in major changes in use patterns (see table 16).

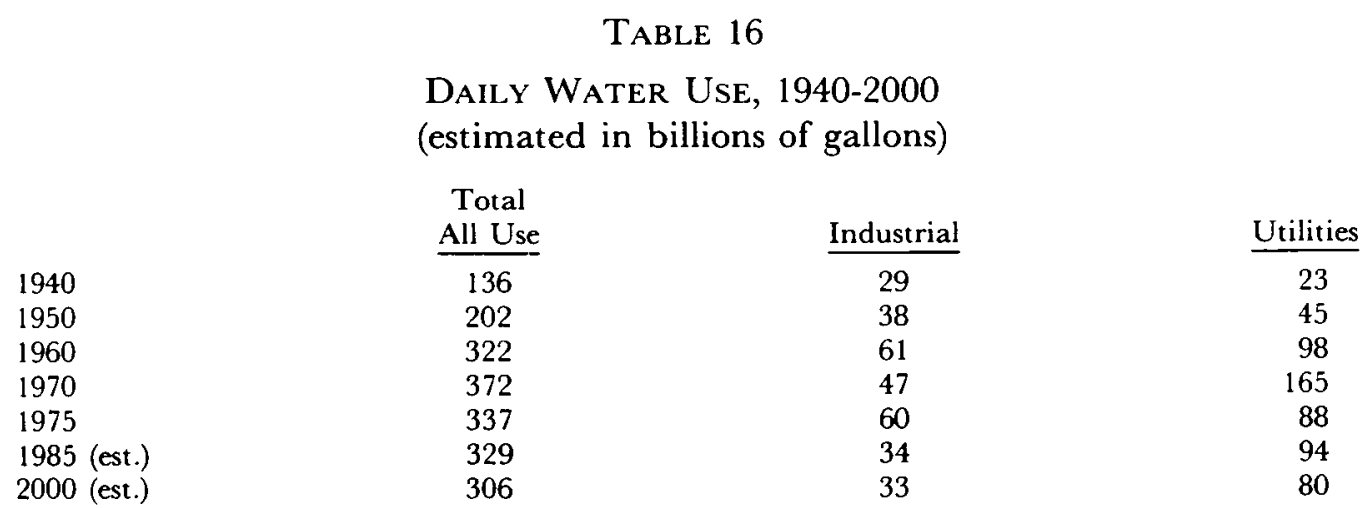

Source: U.S. Dep't of Commerce, Statistical Abstract of the U.S., U.S. Department of Commerce Survey of Current Business 208 (1980).

During the 1970's, the chemical industry devoted significant research to process improvements in order to increase yields of prime products through improved catalysts and control of reaction variables, recycling of partially converted streams, and improved separation techniques. Unfortunately, no comprehensive data on 
these improvements are available. However, yield improvements of $5 \%$ to $15 \%$ are thought to have been achieved in such major processes as vinyl chloride polymerization, ethylene and propylene oxide production, and styrene and maleic anhydride.

\section{Changes in the Occupational Environment}

1. Exposure to Chemical Substances. OSHA adopted permissible exposure levels for some 400 substances in $1972 .{ }^{85}$ These standards were previously developed over the years by the American Conference of Governmental Industrial Hygienists (ACGIH) and published in 1968. Since that time the ACGIH has issued over 150 new recommendations and has revised about sixty of the 1968 recommendations downward. Most companies in the chemical industry, at least the large- and medium-sized ones, have occupational health programs staffed by professional industrial hygienists who establish control programs often targeted at or below the ACGIH recommendations. The proceedings of a 1981 Banbury Conference $^{86}$ outline a number of case examples believed to be typical of trends in occupational exposure occurring over the last thirty years and representative of profile differences between various subsets of employees associated with given substances. Examples cited include a five-to-twenty-fold reduction in exposure to caustic soda (sodium hydroxide) accomplished over a twenty year period through process improvement; ${ }^{87}$ similar reductions in workplace exposure to styrene, acrylonitrile, and benzene; ${ }^{88}$ and imposition of engineering and personal hygiene controls to achieve reduction in environmental concentrations of arsenic and various levels of urinary arsenic in arsenic smelter and processing operations. ${ }^{89}$

In the late 1970's, du Pont toxicologists identified hexamethylphosphorictriamide as a very potent animal carcinogen. Immediately, du Pont initiated extensive retrofitting of their production and handling facilities. ${ }^{90}$ Exposures were reduced from $100 \mathrm{ppb}$ to $0.5 \mathrm{ppb}$ over a one or two year period. Analytical methods were developed and an extensive monitoring program was established. Protective equipment, administrative controls, and engineering controls constituted part of the risk-management program.

Vinyl chloride represents, perhaps, the classic example of exposure reduction by a fairly broad segment of industry. Recently, J. Stafford in England has estimated vinyl chloride exposure levels on a generalized basis for the industry. ${ }^{91}$ These levels, shown in table 17, indicate that peak levels (in the order of 1,000 or more ppm) were believed to be prevalent in the industry in the 1950's.

85. Toxic and Hazardous Substances, 29 C.F.R. $\$ 1910.1000$ (1982).

86. Hoerger, supra note 62 , at 435 .

87. Id. at 444 .

88. Id. at $445-46$.

89. Id. at 446.

90. Statement by Bruce Karrh, The Proposed Rule on Identification, Classification and Regulation of Potential Occupational Carcinogens, OSHA Docket No. H-90, app. B, at 3-8 (filed Feb. 28, 1978).

91. Address by J. Stafford to Society of Environmental Engineers (Mar. 8, 1978); accord Barnes, Vinyl Chloride and the Production of PVC, 69 Proc. ROYAl SOCIETy MED. 279 (1979). 


\section{TABLE 17}

\section{Estimated Exposures of Vinyl Chloride in Polyvinyl Chloride Plants}

\begin{tabular}{lc} 
& $\mathrm{Ppm}$ \\
\cline { 2 - 2 } $1945-55$ & 1000 \\
$1955-60$ & $400-500$ \\
$1960-70$ & $300-400$ \\
mid-1973 & 150 \\
1980 & $<1-10$
\end{tabular}

It is significant that the cases of angiosarcoma of the liver associated with exposure to vinyl chloride have been clustered in relatively few plants (table 18). For example, of the thirty-six cases of angiosarcoma identified in North America, thirty-one of the cases have been clustered in four plants; forty-three of forty-nine plants have never had cases of angiosarcoma. ${ }^{92}$

TABLE 18

\section{Clustering of Liver Angiosarcoma Cases in} Vinyl Chloride Monomer Plants

\begin{tabular}{lcc} 
Western Europe & $\begin{array}{c}\text { No. of cases } \\
\text { cluster/total }\end{array}$ & $\begin{array}{c}\text { No. of factories } \\
\text { in clustered cases }\end{array}$ \\
\cline { 2 - 3 } North America & 35 of $\mathbf{4 3}$ & 10 \\
Rest of world & 31 of 36 & $\mathbf{4}^{\mathbf{a}}$
\end{tabular}

a 43 of 49 factories have had no cases.

Data from J. Stafford (unpublished results).

Approximately twenty chemicals have been causally linked to the development of human cancer. ${ }^{93}$ The widespread media attention given to some of these incidents, coupled with the widespread reporting of animal carcinogenicity testing results, has led to many repetitive suggestions that the United States is experiencing a virtual cancer epidemic. ${ }^{94}$ The rapid rate of growth in the production of synthetic organic chemicals is frequently cited simultaneously. The inference is made that chemicals are contributing to something approaching a cancer epidemic. ${ }^{95}$ Not only are these reports very misleading, but the allegation of cause and effect presumably drawn from these reports is simply not true.

Indeed, reliable studies published by the American Cancer Society show that after the raw cancer mortality data is corrected for yearly increases in population and for the contribution of smoking, the cancer death rate has actually decreased

92. Address by J. Stafford, supra note 91 (citing Worldwide Registry of Liver Angiosarcoma compiled by Imperial Chemical Industries, Welwyn Garden City, Herts., Eng.).

93. International Agency for Research on Cancer, Evaluation of Carcinogenic Risk to Humans (IARC Monograph Supp. I, 1979).

94. See, e.g., Miller \& Miller, Delecting Cancer, Sierra Club Bull., Mar.-Apr. 1981, at 19.

95. Davis, Bridbord \& Schneiderman, Estimating Cancer Causes: Problems in Methodology, Production and Trends, in Quantification of Occupational Cancer 309 (Banbury Report No. 9, 1981). 
slightly over the past several decades. ${ }^{96}$ The production of synthetic organic chemicals experienced its most rapid rate of increase in the period 1940 to 1960 , about 1300 times. Production increased at a more moderate rate from 1960 to 1980 , about four and one half times (see figure 4). Even allowing for a twenty year latency period for cancer induction, if the increase in chemicals was a cause of increased cancer mortality, that should be statistically evident by now.

2. Safety in the Workplace. The chemical industry has always maintained a favorable safety record compared to other industries, and its safety record has shown steady improvement. Table 19 gives comparable data for 1975, the first year such data was reported to OSHA, and for 1980, the latest year that data was available.

TABLE 19

\begin{tabular}{|c|c|c|c|}
\hline Year & $\begin{array}{l}\text { Chemical } \\
\text { Industry } \\
\text { Ranked } \\
\end{array}$ & $\begin{array}{l}\text { Recordable Incident } \\
\text { Rate per } 100 \text { Workers } \\
\end{array}$ & $\begin{array}{c}\text { No. of Cases with } \\
\text { Days away from Work } \\
\text { per } 100 \text { Workers }\end{array}$ \\
\hline 1975 & 6 & 4.62 & 1.1 \\
\hline 1980 & 1 & 3.23 & 0.69 \\
\hline
\end{tabular}

Sources: Chemical Manufacturers' Association, Industry Injury Report (1976 \& 1981); National Research Council, Accident Facts (1976 \& 1981).

Statistics showing the performance of other industries are shown in figure 6 .

E. Changes in Human Health and in Environmental Populations

The majority of HE\&S concerns of the 1970's have been based on the fear of man's activity adversely affecting human health or that of other valuable species. Data on the overall health of human and other populations is sparse. There is no body of data to answer the question whether our investments in chemical and pollution control have paid health dividends. The most that can be reasonably concluded is that indirect evidence discloses no major trend. On balance, average life expectancy has increased since 1900. (Data on life expectancy are shown in 
Figure 6

\section{InCidence Rates of PRincipal Industries Reporters to the National Safety Council}

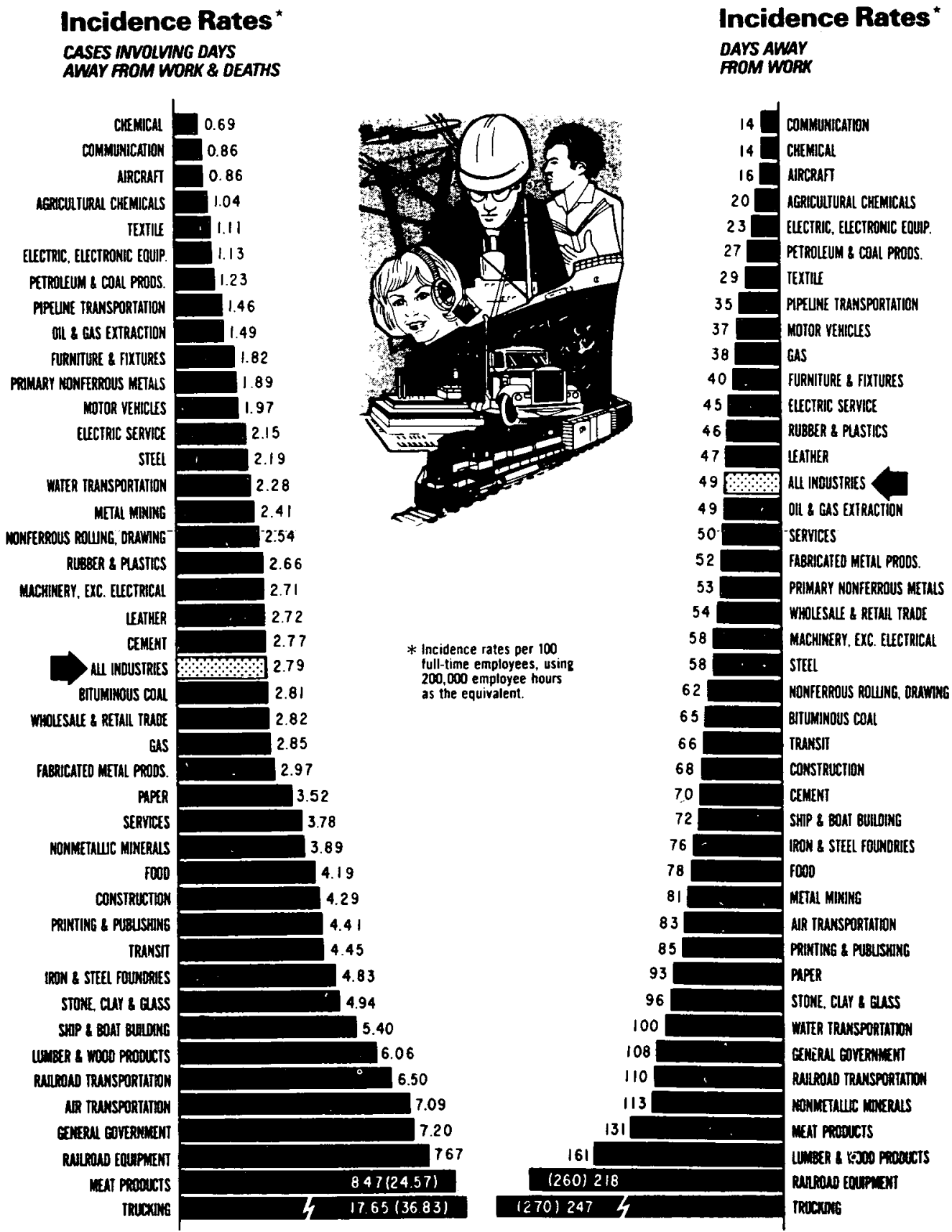

NATIONAL SAFETY COUNCIL 
table 20.) In the early years, public and personal hygiene measures along with vaccines conquered many fatal infant and childhood diseases. More recently, progress in diagnosis and treatment of heart disease and childhood cancer has been achieved. Thus, a shift in the pattern of disease and mortality has occurred.

TABLE 20

EXPECTANCY OF LifE AT BIRTH

$$
\begin{aligned}
& \frac{\text { Year }}{1900} \\
& 1910 \\
& 1920 \\
& 1930 \\
& 1940 \\
& 1950 \\
& 1960 \\
& 1970 \\
& 1978
\end{aligned}
$$

Life Expectancy in Years

47.3

50.0

54.1

59.7

62.9

68.2

69.7

70.9

73.3

Source: Historical Statistics of the United States. Colonial Times to 1970, U.S. Dep'T OF Commerce, Statistical Abstract of the U.S., Survey of Current Business (1980).

One can only speculate whether human health will be improved by new occupational or environmental regulations which are imposed on a national scale. It appears plausible to suggest that the health concerns associated with chemicals are primarily of a local nature. For example, the incidence of angiosarcomas associated with vinyl chloride during the 1970's occurred in only six plant locations in North America. The data on ambient air quality presented in section $\mathrm{V}$ suggest an approach by regional or metropolitan areas. Chemicals produced solely in one of the ten "EPA regions" represent a significant fraction of the universe of chemicals.

\section{The Cost of HE\&S Activity-A Significant OVER Head}

During the past decade, much has been published on the costs of pollution abatement, excessive regulation, and diversion of resources. Countless special studies have gathered information. Generally, the estimates relate to direct capital and operating costs, indirect cost impacts through resource reallocation, and impacts on innovation. Exemplary information will be presented on each.

\section{A. Estimates of the Direct Costs of HE\&S Activities}

Air and water pollution control projects represent the greatest areas of capital expenditure. The EPA estimates that $\$ 150,000,000,000$ in capital has been invested to control air pollution since the passage of the Clean Air Act in 1970. Capital expenditures for water pollution control appear to have been comparable: Capital expenditures for the mid-1970's for air, water, and solid waste are shown 


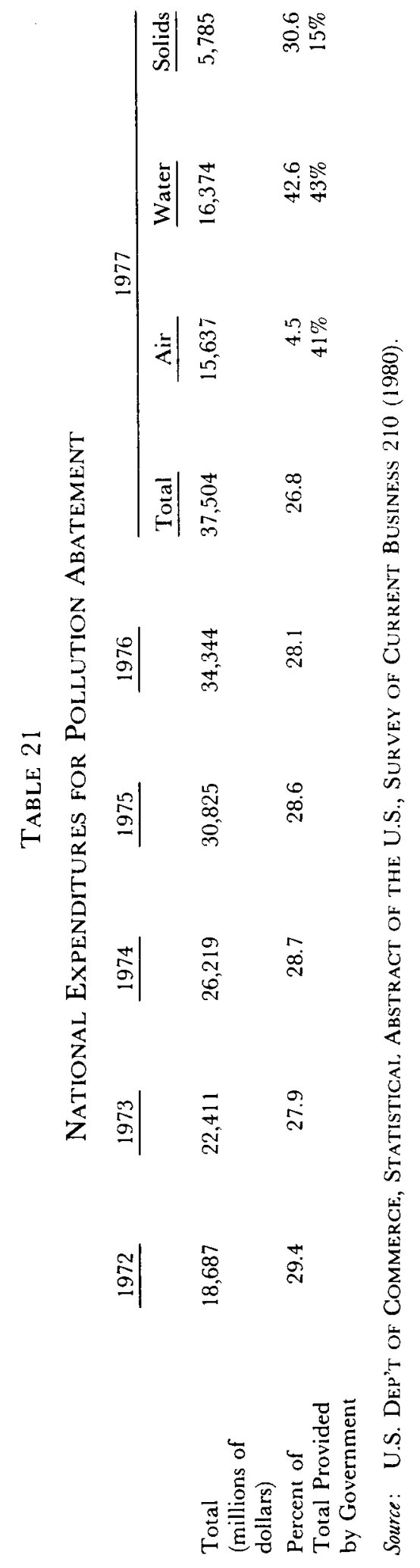


TABLE 22
Pollution Abatement Capital Expenditures and Operating Costs of the Chemical and Allied Products
INDUSTRY, 1973-1980
(millions of dollars)

\begin{tabular}{|c|c|c|c|}
\hline \multirow[b]{2}{*}{ Year } & \multirow{2}{*}{$\begin{array}{c}\text { Total } \\
\text { Capital } \\
\text { Expenditures } \\
\end{array}$} & \multicolumn{2}{|c|}{ Pollution Abatement } \\
\hline & & Capital & $\begin{array}{c}\text { Gross Annual } \\
\text { Operating Costs }\end{array}$ \\
\hline 1980 & N.A. & 795 & 1,865 \\
\hline 1979 & 7,829 & 785 & 1,679 \\
\hline 1978 & 7,956 & 842 & 1,483 \\
\hline 1977 & 8,199 & 1,000 & 1,247 \\
\hline 1976 & 7,122 & 942 & 984 \\
\hline 1975 & 6,333 & 780 & 807 \\
\hline 1974 & 5,071 & 539 & 643 \\
\hline 1973 & 3,186 & 396 & 502 \\
\hline
\end{tabular}

Source: U.S. Current Indus. Re.PORTs, MA-200-1, Pollution Abatement Costs and Expenditures (1980).

in table 21. Total capital expenditures doubled between 1972 and 1977. Data from 1977 show about $15 \%$ of expenditures for solid waste with $41 \%$ for air and $43 \%$ for water pollution control. The private sector provided more than $70 \%$ of total abatement capital and nearly all the investment in air controls.

Capital expenditures for pollution abatement for the chemical industry essentially have doubled from 1973 to 1980 and have been in the order of $\$ 800,000,000$ to $\$ 1,000,000,000$ during each of the past three to four years. Gross annual operating costs have more than trebled during this period and approached $\$ 2,000,000,000$ per year in 1980 (see table 22).

Statistics on expenditures for occupational safety and health are available from surveys published by McGraw-Hill.97 Such expenditures, shown in table 23, nearly doubled between 1972 and 1979.

97. De Bernard, OSHA: Overpriced and Under the Gun, in CONGressional ACtion 4 (Nov. 9, 1979) (citing a survey conducted by McGraw-Hill). 


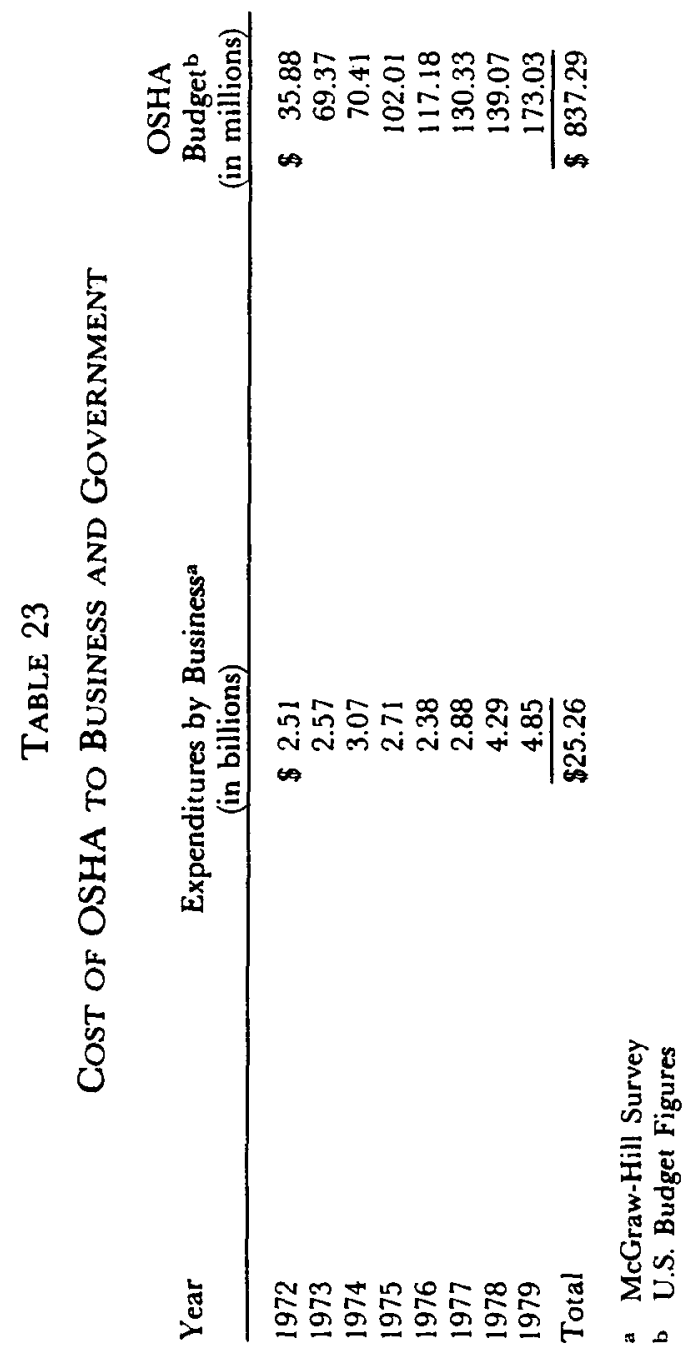




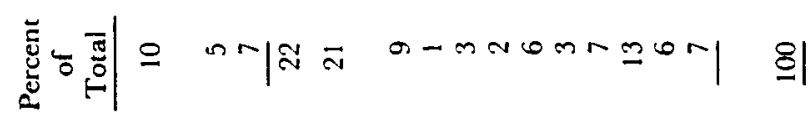

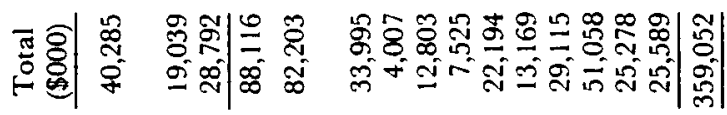

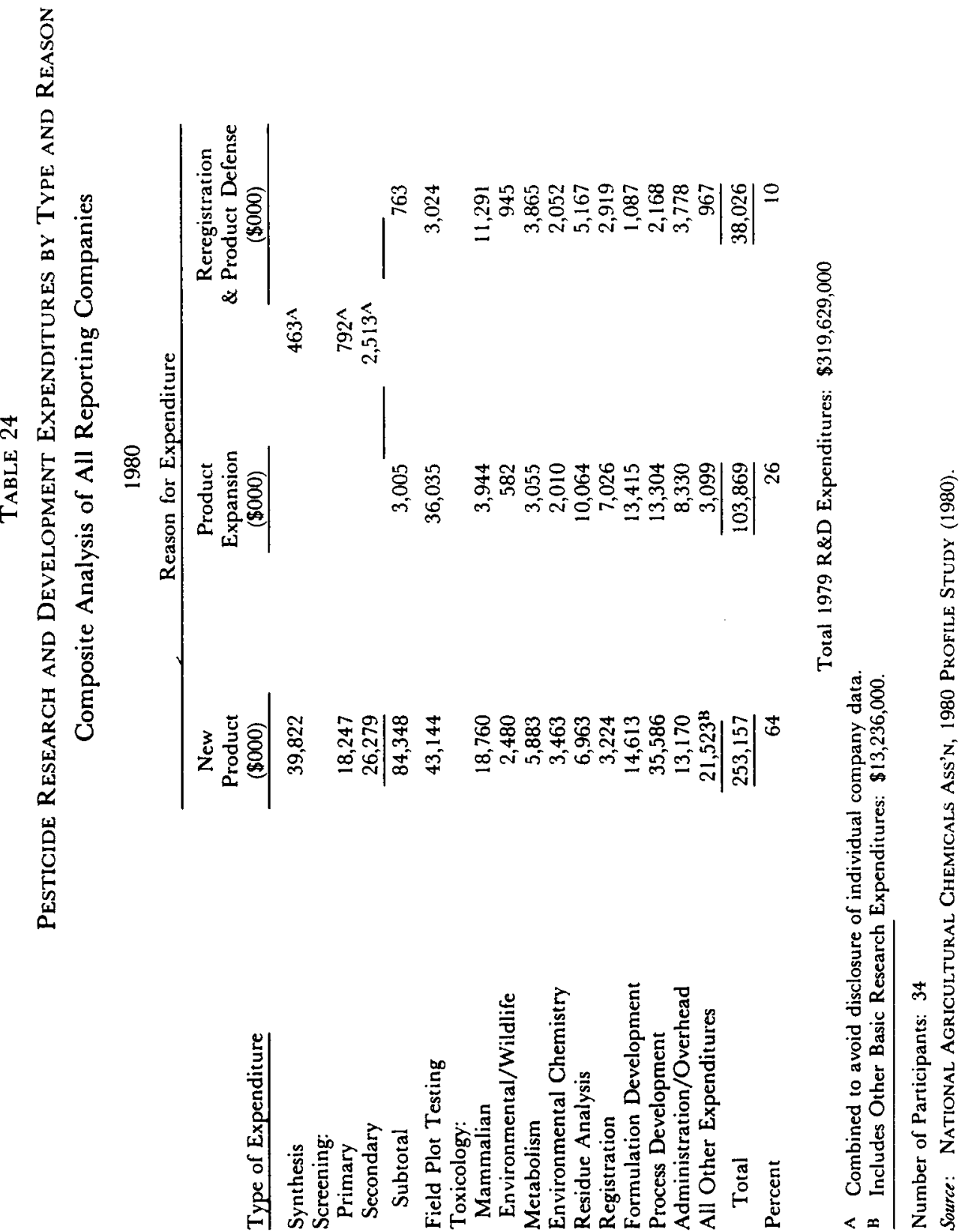


Pesticides have been one of the targets of media, activist, and Congressional scrutiny during the 1970's. Health and environmental studies have been emphasized by industry. Additionally, the National Agricultural Chemicals Association (NACA) collects statistical information on research and development expenditures in this area. The data, shown in table 24, indicate 1980 research and development expenditures of nearly $\$ 400,000,000$. Expenditures directly associated with health, environmental, and safety evaluation amounted to $24 \%$ of this total. This constitutes a greater investment in HE\&S than in other categories, such as discovery, evaluation of efficacy, formulation, or process development.

Numerous bans on products were imposed during the 1970's. The financial impact of such bans has been pronounced. For instance, the EPA estimated that the phasing out of PCB's in mineral oil transformers alone will result in costs in excess of $\$ 612,000,000$ during the next thirty to forty years. ${ }^{98}$ Banning the use of certain chlorofluorocarbons under TSCA in 1978 resulted in a sales loss of $\$ 1,000,000,000$ to the manufacturers in the first four years of the ban. ${ }^{99}$ Monsanto estimated that the banning of their plastic beverage bottles by FDA resulted in losses of $\$ 65,000,000$ of capital investment, $\$ 100,000,000$ in 1980 sales, and nearly 1,000 jobs. ${ }^{100}$ The suspension of a minor-volume herbicide, silvex (used as a component of lawn fertilizer), by the EPA in 1979 resulted in a government recall estimated to have cost more than $\$ 20,000,000 .{ }^{101}$ Ironically, much of the recalled material still awaits waste disposal.

\section{B. Impact of HE\&S Activity on Capital Formation}

During the past few years, the United States has experienced a shortage of capital and concomitant increase in competition in automobiles, textiles, steel, electronics, and other goods. At the very time that American industry needed to invest in new technology and retool by replacing relatively obsolete plants, the requirment for $\mathrm{HE} \& \mathrm{~S}$ capital brought added competition for the available investment capital.

The chemical industry may be contrasted favorably with some of the other industries because of its high rate of innovation and generally higher unit return on product. However, the chemical industry's percentage of capital investment for pollution abatement is also higher than that of general manufacturing, as shown in table 25.

Further, the chemical industry generally invests around $66 \%$ of its available funds in the replacement of existing plant capacity. Thus, it can be seen that approximately $10 \%$ of the capital required for pollution abatement represents a significant portion of the otherwise discretionary $34 \%$ remaining after replacement of capacity. This abatement capital significantly reduces the industry's discretion

98. See EPA Proposed Rule, 43 Fed. Reg. 24,811 (proposed June 7, 1978).

99. EPA Final Action Support Document for Fully Halogenated Hydrocarbons 12 (Mar. 17, 1978).

100. Telephone interview with W.J. McCarville, Environmental Policy Manager of the Monsanto Company (May 1982).

101. Author's estimate. 
to invest in increased capacity and its ability to obtain funds for product and process innovation.

TABLE 25

Capital Expenditures by Business for Pollution Abatement

$\%$ of Total Capital

\begin{tabular}{lrrrr} 
& \multicolumn{1}{c}{1975} & $\underline{1976}$ & \multicolumn{1}{c}{$\mathbf{1 9 7 7}$} & $\underline{1978}$ \\
\cline { 2 - 5 } Manufacturing & 9.3 & 8.3 & 7.0 & 5.8 \\
Chemical Industry & 10.9 & 11.4 & 10.2 & 7.8 \\
Non-Manufacturing & 3.2 & 3.5 & 3.5 & 3.5 \\
All Industry & 5.8 & 5.6 & 5.1 & 4.5
\end{tabular}

Source: U.S. Dep'T of Commerce, Statistical, Abstract of the U.S., Survey of CurRent BUSINESS 211 (1980).

\section{Impact of HE\&S Activity on Innovation}

Various studies and policy deliberations have focused on the trends in American innovation during the past decade. These discussions have ranged from the possible influences of regulation to the effects of foreign competition. Before examining a few key trends and possible causal relationships, it seems worthwhile to characterize the fragile commodity called innovation: the process of creation, development, use, and diffusion of a new product or process for new or already identified needs. ${ }^{102}$ Former President Carter stated: "Innovation is a subtle and intricate process, covering that range of events from the inspiration of the inventor to the marketing strategy of the eventual producer."103 And Peter Drucker has characterized technological innovation as "a conscious attempt to bring about, through technology, a change in the way man lives." 104 A more comprehensive characterization within the context of industry is:

The innovation process may be considered as having four sequential phases:

1. Generation of a reliable body of scientific and technological knowledge and concepts.

2. Synthesis, the coalescing of the perceived need into the necessary know-how to create useful goods. This is done by defining problems and creating solutions.

3. Demonstration, showing in a practical way the functional utility and economic viability of the concept formulated in the second step, that is, a proof of technical feasibility, economy, and market acceptance.

4. Diffusion: Widespread application of the idea, eventually tapering to the rate of industrial growth. ${ }^{105}$

Considering the breadth of these definitions, any assessment of innovation trends might focus on quantity (either ideas or commercialized products, processes, or ventures), quality, and uniqueness of value judgments (for example, the hula-

102. Maier \& Haustein, Innovation, Efrciency Cycle, and Strategy Implications, in Technological For ECasting and Social. Change 17, 35-49 (1980).

103. President's Message to Congress Transmitting Proposed Initiatives, 15 WeEkly CoMP. Pres. DOC. 2072-73 (Oct. 31, 1979).

104. Conservation Foundation, Product Regulation and Chemical innovation 1 (1980).

105. Environmental Panel of the Environmental Safety \& Health Subcomm., Advisory Comm. on Federal Policy on Industrial InNOvation, Final Report 7-8 (1978). 
hoop, a safe football helmet, an artificial kidney, or a solar collector system). Additionally, the contribution of innovation to economic growth has been the subject of much research and scientific literature.

Generally, there seems to be a widespread consensus that the rate of American innovation decreased during the 1970's, while the rate of innovation in several countries, notably Japan and West Germany, increased significantly. This belief is supported by the increased market share of foreign-produced goods in several U.S. technology markets (for example, steel, autos, cameras, radios, and televisions). Considering the "front end" of the innovation cycle, the total number of patents issued annually in the United States has declined moderately since 1971. There has been, however, a more significant decrease in the number of patents granted to U.S. residents. There has also been a marked increase in the number of patents granted annually to foreign residents (see figure 7).

FIGURE 7

\section{U.S. Patents Granted, by Inventor}

AND DATE OF GRANT, 1960-76

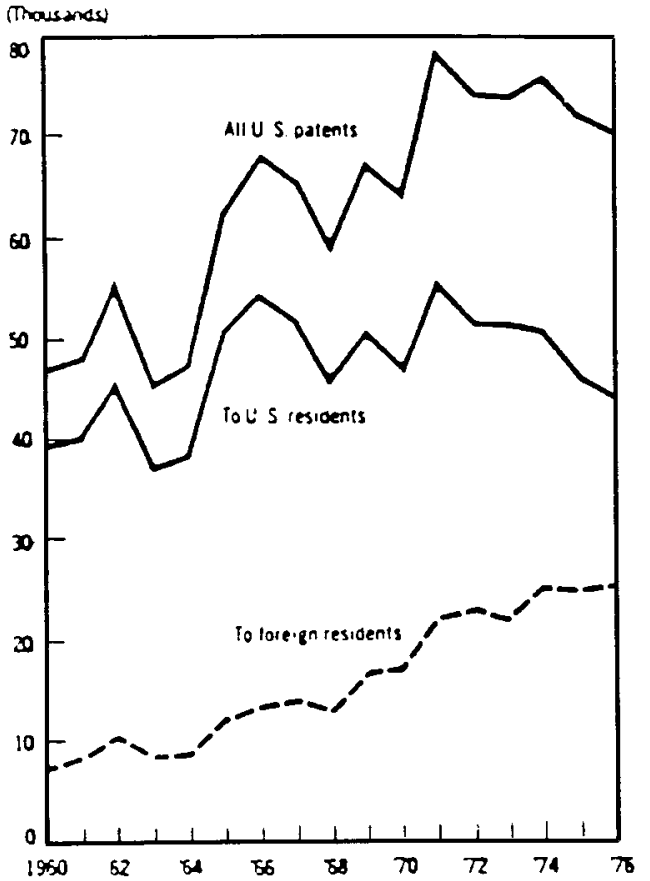

Source: Report of the Advisory Subcomm. on Patent and Information Policy of the Advisory Comm. on Indus. Innovation (1979).

Another gross indicator of innovation, U.S. spending in research and development, as a percentage of GNP, has decreased since 1963 (from $2.87 \%$ to $2.25 \%$ in 1978). ${ }^{106}$

106. National Science Foundation, Science Indicators-1978 at 140, table 1.1 (1979). 
With increasing attention focusing on the U.S. economy in relation to international markets, it seems important and appropriate to examine the relationship of innovation to exports. Research and development (R\&D) intensive products, in contrast to non-R\&D intensive products, contribute significantly to the U.S. balance of trade (see figure 8 ). The chemical industry is manifestly one of the R\&D intensive industries at $2.51 \%$ of sales, and, as such, it follows the general pattern. Indeed, chemical industry exports have ranked second only to agricultural products for a number of years. The chemical industry achieved a balance of trade surplus of $\$ 11,600,000,000$ in $1981 . .^{107}$ The National Academy of Sciences, in a

FIGURE 8

U.S. Trade Balance (Exports Less Imports) in R\&D-INTENSIVE and Non-R\&D-InTensive Manufactured Product

GROUPS, (1960-1978)

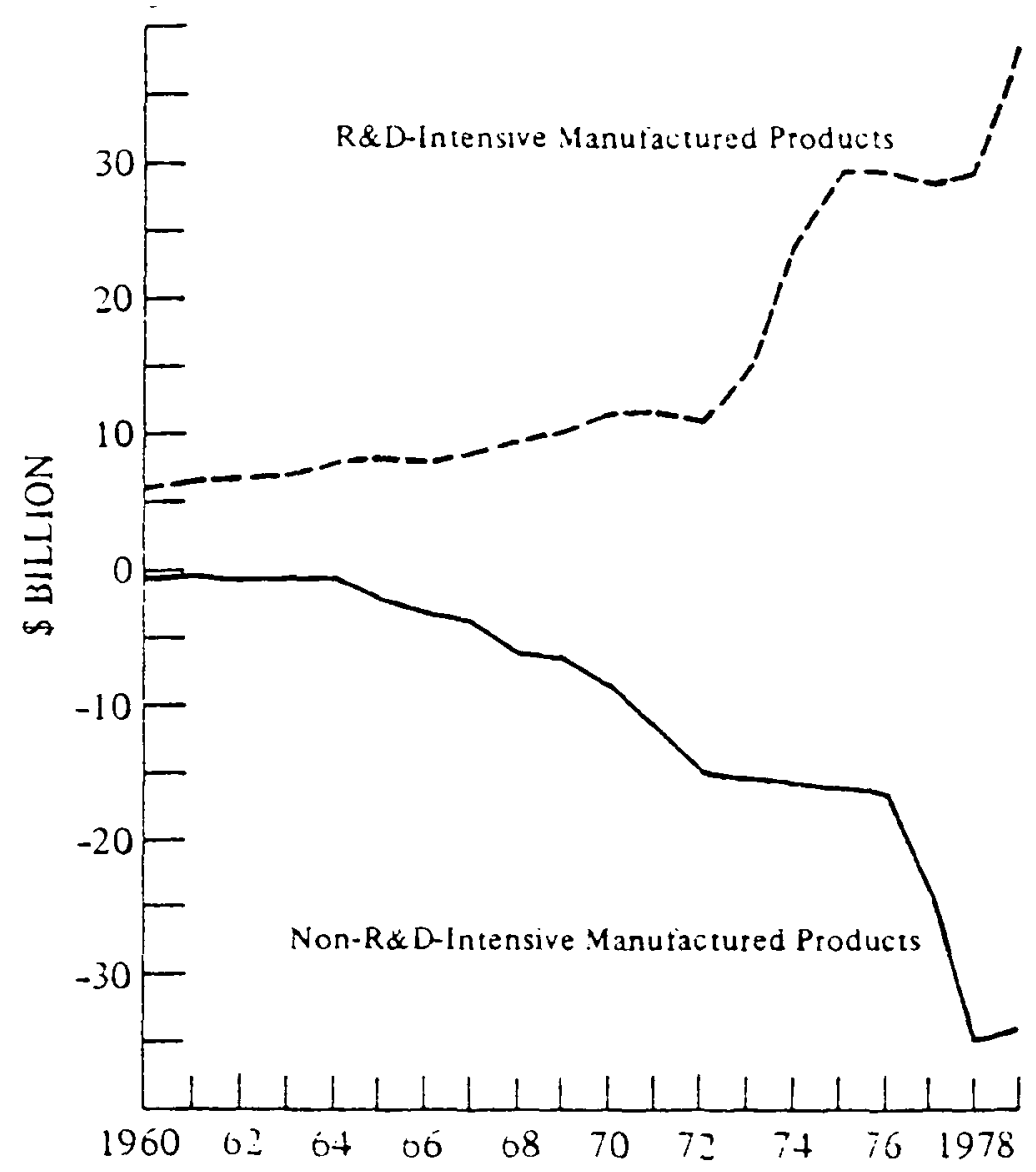

Source: Adapted from National Science Foundation, Science Indicators (1978).

107. See Bureau of the Census, U.S. Dep't of Commerce, Highlights of U.S. Export \& IMPORT TRADE (1981). 
1981 outlook on science, made two significant conclusions:

America's place in the international competitive arena can be assured by maximizing its competitive edge, by returning to the forefront of the technological innovative process, and by utilizing fully the unique fundamental research capacity and the hugh industrial research capability already in place....

In an ever shrinking, overpopulated world of finite mineral resources, where arable lands may be reaching their carrying capacity for human populations, further improvements in the human condition will require that we live by our productive imagination and wits, using scientific understanding for the development of ever more effective and efficient technologies. The one resource which is still unlimited is man's ability to seek out, to comprehend, and to find the paths and institutions through which his new comprehensions can be translated productively into social purposes. ${ }^{108}$

This same report acknowledged the justification for the considerable belief that American innovative capability has declined. Several factors were listed as possible causes for this decline: inflation, lack of investment capital, deflection of company resources or the diversion of management from the innovation process to the requirements for compliance with regulation, and probably other factors as well. 109

This discussion of the innovation process has been somewhat comprehensive in order to emphasize its national importance, complexity, and fragile nature. Despite numerous studies, it is difficult to make either a simple or conclusive statement about the impact of the HE\&S trends of the 1970's on innovation. A few facts, however, are worthy of note. The institutional changes that have occurred in the chemical industry ${ }^{10}$ make it apparent that scientific and technical manpower have been diverted from traditional chemical research and development into $\mathrm{HE} \& \mathrm{~S}$ activity. Observations of the authors suggest that perhaps as much as $10 \%$ to $20 \%$ of chemical industry research and development is motivated primarily by $\mathrm{HE} \& S$ concerns (including inquiry into substitute products with greater $\mathrm{HE \& S}$ "acceptability"). This percentage of $\mathrm{R} \& \mathrm{D}$ in $\mathrm{HE} \& \mathrm{~S}$ matters has certainly doubled in the decade-perhaps quadrupled. Moreover, the trend was still upward at the end of the decade.

It is generally accepted that there has been a decline in the development of new pesticides and new drugs in the United States during the 1970's and there is fairly widespread agreement that extensive regulation of these two industry segments is at least partially responsible. For example, in 1966, twenty-eight new agricultural pesticide chemicals were registered. This number fell to ten in 1974 and hit a low point of zero in 1977. In 1980, no "full" registration was granted for new pesticides, but "conditional" registration" " was granted for seven substances. "12 Based on the experience of the pesticide and drug industries, considerable debate has occurred since the 1976 passage of TSCA on the impact of premanufacture notification on innovation. Carl Umland, who recently analyzed three years of TSCA

108. National Research Council, National Academy of Sciences, Outlook for Science \& Technology: The NeXt Five Years 5-6 (1982).

109. Id. at 6.

110. See supra section IV

111. A "conditional registration" is contingent upon completion of additional testing and the continued absence of unreasonable health or environmental risks.

112. National Agricultural Chemicals Ass'v, 1980 Profile Study 2-3 (1980). 
experience, ${ }^{113}$ concluded that already the new regimen has exerted a negative impact on chemical innovation. He cites data to show a decline in the number of new chemicals introduced each year, ${ }^{114}$ a shift away from low-volume chemicals, ${ }^{115}$ and a predominance of the new chemical introductions made by large companies. ${ }^{116}$ With increasing national attention focusing on trends in innovation decline and increasing recognition of the need for economic growth, it is expected that fostering, or at least not unduly impeding, the climate for innovation will receive added emphasis in $\mathrm{HE} \& \mathrm{~S}$ policy forums.

\section{VII}

\section{The NeEdS FOR THE 1980's BASEd ON THE EXPERIENCE OF THE 1970's}

\section{A. Principles Learned in the 1970's}

It has become increasingly and alarmingly apparent that there is a finite limit to the resources that can be applied to HE\&S matters. To illustrate the obvious restraints on resources-people, know-how, and dollars- consider that toxicological research and testing is limited by a shortage of pathologists; the reality and significance of a "green-house effect" remains an uncertainty due to the limit of our ability to generate useful knowledge; and investment in pollution-control facilities can be limited by the capacity of an industry to generate capital.

The need to set priorities is an obvious and inexorable consequence of limited resources. Two observations seem pertinent. First, the HE\&S laws addressed perceptions of problems at the time of enactment and were based on an implicit assumption that the problems would continue without government intervention. Thus, from a Congressional standpoint, there has been little overall ranking or review of the totality of the HE\&S priorities. To some degree, annual budget appropriations may reflect some focus on priorities. This sense of priorities is, however, influenced strongly by a need to provide the resources required to fulfill the mandates of the past. Second, most HE\&S statutes leave considerable discretion to the agencies in setting their priorities. Although the process of promulgating a regulation involves considerable public participation, the process by which an agency establishes its priorities is largely closed. Mr. Richard Denny, a former EPA attorney, observed that what is regulated is as important as how it is regulated. The point is that neither Congress nor the various agencies have established forums or decision processes that address priorities on a broad conceptual or analytical basis. Both institutions are largely reactive.

One of the problems of the 1970's was that most of the monitoring programs were designed to measure progress toward the goals of pollution abatement and, at most, were only indirect indicators or surrogates for the state of health or environmental quality. The time has come for research, fact finding, discussion, and

113. C. Umland, The Future of Innovation Under TSCA (Mar, 31, 1982) (unpublished manuscript).

114. Id.

115. Id.

116. Id. 
assessment of the further advances that can be made in health quality through improvement in environmental quality. The legislative goals of the 1970's were based partly on idealism and partly on a belief that reasonable improvements could be achieved. Now that significant improvement has been achieved, the goals for the regulatory progress of the latter 1980's must be based on the wisdom gained from new information and new perspectives which reflect the attainable balancing of health and environmental investments with other societal values.

\section{B. Statutory and Regulatory Concepts Which Have Outlived Their Usefulness}

Based on the premises that HE\&S quality has improved significantly, that the nation has limited resources, and that future policy decisions will place greater emphasis on attainable priorities, it is plainly evident that several regulatory concepts have outlived their usefulness.

1. Technology Forcing Standards. Technology forcing concepts have been applied widely in the drafting and implementation of the air and water statutes including best practicable technology, best available technology, and lowest achievable emission rates. ${ }^{117}$ These approaches have been instrumental in forcing retrofitting, design of scrubbers, and a whole host of other hardware approaches to control. Within the chemical industry, manufacturing processes have been upgraded to increase yields of prime and useable byproducts, thereby reducing the load on waste treatment and emission facilities. After a decade of technology forcing, few people foresee major new technological advances. An EPA official in 1979 characterized the problem by stating that one can add only so many scrubbers to reduce emissions before the addition of another scrubber will accomplish very little, if anything. Quite clearly, the law of diminishing marginal returns applies with equal force to the application of pollution control equipment.

2. Generic Regulations. In implementing the Clean Air and Clean Water Acts, industries or processes have been divided into broad categories for the purpose of determining the applicability of a particular standard. In 1977 and 1978, OSHA and the Consumer Product Safety Commission (CPSC) developed concepts for the generic regulation of a broad category of substances-carcinogens. In 1980, the

117. McGarity describes "technology pulling" standards as those which "pull" all members of an industry up to the level of the industry leader. McGarity, Media Quality, Technology, and the Utilitarian Ideal: Aliemative Strategies for Health and Environmental Regulation of the Chemical Industry, LAW \& CONTEMP. PROBS., Summer 1983, at 159. To a large degree, this objective has been accomplished for most major processes within the chemical industry.

Ashford discusses the possibility of technology forcing through the development of substitute products to replace products with undesirable risks or products with polluting processes. Ashford \& Heston, Regulalion and Technology Innovation in the Chemical Industry, LAW \& ConTemp. ProBs., Summer 1983 , at 109. Although this may have conceptual appeal, implementation would be fraught with uncertainty. For example, there has been over a decade of debate on the impact of cyclamates, and a similar controversy has raged over saccharin for a somewhat shorter period. In each case, there is still uncertainty over the existence of a viable substitute.

Another complex forecasting uncertainty for regulation involves unknown risk trade-offs. For instance, technology forcing led to the introduction of "tris"--treated sleepwear to meet flammability mandates. By the late 1970's the Consumer Product Safety Commission ruled that the chronic health hazards posed by this "forced" technology were unsatisfactory. 
EPA published Water Quality Criteria for classes of chemicals despite widely varying properties of chemicals within a class. Generic legislative or regulatory approaches, when triggered by a set of predetermined criteria or by presumptions based on incomplete data, lead to "generic" lists of substances with widely varying potential risks. Similarly, generic stipulation of controls for classes or categories leads to variable degrees of residual risk. These approaches, alleged to save agency resources, are cost ineffective. The uniform standard (and thus cost) is applied irrespective of the risk reduction (benefit) that is achieved.

3. Specification Standards in Lieu of Performance Standards. Many standards promulgated by OSHA, and recently by the EPA, under RCRA, specify how results are to be achieved, such as work practices, medical surveillance, and equipment or process specifications. Such specification standards regularize technology to a point in time and across broad segments of a diversified industry. Technology and procedure are thus frozen by the regulation. Such an inflexible approach unavoidably chills incentive for innovation and the achievement of greater efficiency.

4. Yes/No and Ban Decisions. The Delaney Amendment to the FD\&C Act ${ }^{118}$ prohibits the use of any food additive found to be carcinogenic in humans or through appropriate animal tests. The EPA partially utilized this philosophy as justification for banning several pesticides in the early 1970's. ${ }^{119}$ Application of the Delaney Amendment by the FDA in the case of polyacrylonitrile resulted in significant and unrecoverable economic loss to Monsanto. And the proposed banning of saccharin led to public furor and a Congressional moratorium on enforcing the statutes. Congress, in drafting TSCA, banned the further manufacture of polychlorinated biphyenyls (PCBs) and ordered a phase-out of their use. Prohibition of intentional manufacture was not a contested issue, but unintentional manufacture of traces of $\mathrm{PCB}$ in the production of other chemicals has involved a costly industry program and litigation against the EPA by the Environmental Defense Fund. ${ }^{120}$ Simplistic binary decisions are so inflexible and premature that frequently large unforeseeable costs are incurred with little relationship to the benefits achieved. As a result, it is significant that the courts have judicially approved of concepts like the de minimis risk and threshold of significant risk in interpreting the Delaney Amendment ${ }^{121}$ and the feasibility clause of OSHA. ${ }^{122}$

In the late 1970's, the emphasis shifted from "command and control" regulations to a risk-management approach dealing with environmental and occupational hazards. Concepts of significant risk, unreasonable risk, risk assessment, and hazard evaluation began to replace obsolete concepts such as margin of safety and zero-risk. ${ }^{123}$ Hazard abatement became more important than penalties in agency

118. 21 U.S.C. $\S 348$ (c)(3)(A) (1976).

119. These pesticides included dieldren, aldrin, chlordane, heptachlor, and DDT

120. Environmental Defense Fund, Inc. v. EPA, 465 F.2d 528 (D.C. Cir. 1972).

121. 21 U.S.C. $\$ 348$ (c)(3)(A) (1976).

122. 29 U.S.C. $\S 655(\mathrm{~b})(5)(1976)$

123. See generally Toxic Substances Control Act, 15 U.S.C. $§ 2603-2605$ (1982). 
enforcement schemes. The hazard management approach utilized by sophisticated chemical companies began to be accepted by public policymakers.

\section{The Concepts for the Future}

A number of new, or newly emphasized, approaches to regulation are emerging with the purpose of establishing a decisionmaking process which balances a greater number of societal values and thereby achieves greater efficiency and greater consistency. The following are recommended as particularly applicable to the HE\&S aspects of chemicals.

1. Regulatory Analysis: Cost Benefit $\mathcal{E}^{2}$ Cost Effectiveness. Both the Carter ${ }^{124}$ and Reagan ${ }^{125}$ administrations issued executive orders requiring a formal regulatory analysis for major regulations (generally, those expected to have an impact greater than $\$ 100,000,000)$. Each order specified that the reasoning or rationale to support the decision should be stated explicity and that some form of cost benefit or cost effectiveness analysis was required as a condition precedent to promulgation. President Reagan's Executive Order 12,291 is only now being implemented. No clear indications are yet available as to the degree of rigor that will be applied by the agencies. However, the more compelling conceptual power of the cost-benefit directive will have considerable impact on the discretionary activities of the regulatory agencies. Its impact on statutorily mandated agency activities is, however, less clear.

2. Independent Scientific Peer Review. The agencies have been criticized severely for the quality of scientific evidence used to support their decisions and for the inconsistency of many decisions in light of present scientific knowledge. The EPA has a science advisory board and, by statute, ${ }^{126}$ other special science groups made up of non-EPA scientists. In the past, these groups were utilized to comment on regulations at the final stage or to review the EPA's overall programs. Currently, the EPA has issued a policy for these groups to review the scientific data base prior to issuance of a regulatory proposal. This will provide for review of EPA staff work and allow utilization of the expertise of the advisory groups as a basis for a proposal rather than comment after the Agency has made a commitment to a course of action. The FDA utilizes panels of independent scientists in new drug reviews, and occasionally, for other complex scientific issues. Regulatory agencies have had difficulty in attracting and retaining a significant number of eminent scientists. For example, OSHA has had from zero to five physicians on its staff over the past five years. Increased utilization of science panels provides a greater number of professionals who are available for assessment activities by the Agency. An added asset is that these professionals usually are on the leading edge of scientific research which is essential for assessment of complex issues.

124. Exec. Order No. 12,044, 43 Fed. Reg. 12,661 (1978).

125. Exec. Order No. 12,291, 46 Fed. Reg. 13,193 (1981).

126. See, e.g., Toxic Substances Control Act, 15 U.S.C. $§ 2603$ (e) (1982). 
3. A Two-Track Regulatory Framework and a Science Panel. The American Industrial Health Council (AIHC) has advocated that the regulatory process would be most effective if a clear procedural distinction were made between the scientific aspects and the social value aspects of the regulatory process. ${ }^{127}$ Put simply, the scientific component involves the gathering of information and the characterization or assessment of hazard and risk. The social value phase involves evaluation and determination of the need for stringent controls, the weighing of various societal values as directed by statute, and the discretionary authority of the Agency. The AIHC has proposed further that a scientific panel, independent of regulatory agencies, could strengthen the scientific phase of the regulatory process by assessing the hazard posed by a suspected carcinogenic agent. The purpose of the panel is to bring the best available scientific expertise to bear on these questions of potential risk. The independent scientific panel could serve all regulatory agencies and minimize the duplication of agency resources.

4. Priorities and the Regulatory Budget. The Paperwork Reduction Act of $1981^{128}$ establishes a process whereby a ceiling is placed on the amount of burdensome paperwork that an agency can require of the regulated. Goals of a $25 \%$ reduction in paperwork are to be achieved by 1983. Conceptually, Congress made a judgment that the agencies were overburdening the regulated and, as such, applied an arbitrary fix, but left the discretion for priority setting in achieving the goal to the agencies. Some federal budget expenditures, such as defense or social security outlays, are related readily to their impact on the economy. The direct budget of the regulatory agencies is a hidden leverage on the economy. Shifting the budgeting process to an evaluation of the total industry burden would bring regulatory investment into a comparable perspective. Such a change would also foster a greater analysis of the cycle:

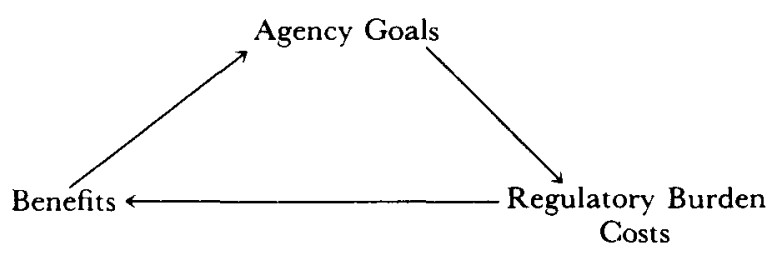

5. Simplification of Statutes. Much has been written about the jig-saw pattern of HE\&S statutes. Frustration is displayed by the regulated in terms of the difficulty and elapsed time in obtaining the myriad permits required for a new venture. Similar frustration is expressed by the activist community concerning the slowness in promulgation of regulations. These frustrations are among many signals for basic change in the HE\&S statutes. Nonetheless, the response to this concern has been characterized by lethargy rather than creative change. One possible route to

127. american Industrial Health Council, Inc., Chronic Health Hazards: Carcinogenesis, Mutagenesis, Teratogenesis, a Framework for Sound Science in Federal DecisionMAKING (1981).

128. 44 U.S.C. $\S 3501$ (Supp. V 1981). 
creative change lies in an analysis of the checks and balances in our system today compared to 1970 .

At the risk of redundancy, let us review the checks and balances. We now have an expanded knowledge base on chemicals; disclosure of HE\&S matters; public participation processes; institutionalization of $\mathrm{HE \& S}$ matters in the industry; increasing emphasis on liability; and a comprehensive fabric of laws and regulations. The time seems ripe to consider seriously and aggressively a readjustment of the checks and balances in our approaches to HE\&S matters. An institutionalized cadre of HE\&S professionals is currently dedicated to expanding the HE\&S data base, solving HE\&S problems, and upgrading HE\&S quality. Professionalism, public visibility, and public participation can achieve priority setting in many meaningful ways.

The first challenge is to reevaluate our statutes and regulations, and to weed out the inflexible and inefficient clauses, lists, and directives. The preceding lists of obsolete concepts and future concepts are prime candidates for modernizing our system of checks and balances. The second challenge is to address the sense of equity and fairness in our liability proceedings. In the 1970's, we determined our HE\&S priorities and standards on a societal basis. A major new body of law was developed in a time frame that was only fleeting in the chronological history of law. The law was created faster than technology, science, and rational political process conceivably could permit. Corporate compliance with the laws and regulations of the decade of the 1970's must be judged as a valid code of conduct on matters of risk and hazard. The chemical industry today is at a crossroads. It has made substantial human and monetary investments in HE\&S quality; results have been achieved. Yet, it is faced with a continuation of new regulations and a liability exposure unprecedented in its history. To the extent that these two forces are paramount pressures, the industry may well have to divert resources from longer term data generation and problem solving, which will severely handicap the industry in its attempt to meet the technological and competitive challenges of the remaining decades before the close of the 20th century.

\section{VII \\ SumMary aNd CONCLUSIONS}

A. Five fundamental forces have impacted on the chemical industry in health, environment, and safety (HE\&S) matters during the 1970's:

1. Dramatic advances in health, environmental sciences, and in control technology.

2. Expanding concept of corporate responsibility.

3. Increases in media sensationalism, interest group advocacy, and public participation.

4. Drarmatic expansion of the laws and regulations impinging on the chemical industry.

5. An increasing number of liability suits.

B. The numerous HE\&S statutes enacted have fostered a variety of regulatory approaches: technology forcing standards, action and time forcing directives, per- 
formance and specification standards, and risk analysis balancing the likely social and economic consequences.

C. The HE\&S activities and considerations have become institutionalized in the corporate organization and are highly integrated into the managerial decision process. The institutionalization of HE\&S programs and the evaluation of research and risk potentials has occurred in intercompany organizations and by scientists throughout the public and private sectors.

D. The HE\&S achievements of the 1970's were substantial when evaluated from two perspectives:

1. The level of knowledge regarding the health and environmental effects of chemicals increased substantially during the 1970's. Comprehensive toxicity and ecological data have been made available on those chemicals which constitute a large fraction of total industry output.

2. Indicators of air and water quality, and the occupational environment reveal that substantial progress has been made during the past decade.

E. The industry costs of HE\&S actions escalated sharply during the 1970's. Pollution control (air, water, and solid waste) expenditures now represent $10 \%$ of the total capital investment of the industry. In the larger chemical companies, personnel associated with HE\&S activities represent from $3 \%$ to $5 \%$ of company employment, and approximately $10 \%$ of the professional, management, and administrative personnel. The point of diminishing returns for additional resources expended has been reached.

F. The experience of the 1970's has led to a general concensus that there is a finite limit to the resources that can be expended on HE\&S. Thus, greater attention needs to be given to priority setting and assessment of the limits to improvement in HE\&S quality. Experience elucidates that regulatory concepts such as technology forcing standards, specification standards, generic regulations, and "yes/no" or absolute ban decisions have largely outlived their utility.

G. Needed regulatory and statutory reform requires a focus on regulatory analysis (cost benefit, cost effectiveness), independent scientific peer review, a two-track regulatory framework, a regulatory burden budget, priority setting, and a simplification/streamlining of statutes that follows analysis of the many checks and balances introduced during the 1970's. 
